\title{
Considerations of Choice of Law in the Doctrine of Forum Non Conveniens
}

A frequent consequence of a dismissal under the doctrine of forum non conveniens is that the action is tried under the substantive law of the alternative forum. The Supreme Court held in the 1981 case of Piper Aircraft Co. v. Reyno ${ }^{1}$ that the possibility of a change ni substantive law ordmarily should not be given conclusive or even substantial weight in the forum non conveniens iniquiry. ${ }^{2}$ In May of 1984, a California court of appeal aunounced a significant departure from this federal rule in California forum non conveniens law. In Holmes v. Syntex Laboratories, Inc. ${ }^{3}$ a product hability snit brought by British citizens against a California corporation, the court distinguished California forum non conveniens law froin the federal doctrine articulated in Piper. The court held that, in determining whether an alternative forum is "suitable," California courts are required to consider the possibility that the applicable law in the alternative forum will be less favorable to the planitiff. ${ }^{5}$

Although its precedential value remanis unclear, ${ }^{6}$ the Holmes deci-

1. 454 U.S. 235 (1981).

2. Id. at 247.

3. 156 Cal. App. 3d 372, 202 Cal. Rptr. 773 (1984).

4. Id. at 382, 202 Cal. Rptr. at 779.

5. Id. The Holmes court further held that even a foreign national's choice of a California forum is entitled to substantial deference. 156 Cal. App. 3d at 380-81, 202 Cal. Rptr. at 778. Piper had deternined that iu federal courts, a foreign plaintiff's choice of forum deserves less deference than the choice of a resident plaintiff. 454 U.S. at 255-56.

6. The first California court to give considered treatment to Holmes seemed fainthearted about following Holmes's lead. Rehm v. Aero Engines, 164 Cal. App. 3d 715, 210 Cal. Rptr. 594 (1985). Rehm was an action by non-California plaintiffs imjured in the crash in Canada of a plane whose engine had been overhauled by the defendant, a California corporation. On its facts, the case was quite similar to Piper Aircraft Co. v. Reyno, 454 U.S. 235 (1981). The plaintiffs contended that, under the authority of Holmes, the case could not be dismissed, since Canada did not have strict liability for defective products. $164 \mathrm{Cal}$. App. 3d at 721, $210 \mathrm{Cal}$. Rptr. at 597. Defendant argued, inter alia, that Holmes was wrong in hight of Piper. Id.

The court of appeal declined a straightforward appraisal of Holmes by distinguishing its facts. In particular, it said that Canadian law was not as unfavorable a change from California law as British law had been in Holmes. Id. at 722, $210 \mathrm{Cal}$. Rptr. at 597-98. The court appeared uncomfortable with aspects of the Holmes decision, writing "Although we are tempted to explore some of the interesting questions raised by Holmes, and its diversions from Piper, we are not required to do so to resolve the case at bar." Id. at 721, $210 \mathrm{Cal}$. Rptr. at 597.

A recent California court of appeal decision reversing the forum non conveniens dismissal of a wrongful death action brought by an Australian family against a California heart-valve manufacturer explicitly declined to follow part of the Holmes decision, although it adopted other aspects of the Holmes court's analysis. Corrigan v. Bjork Shiley Corp., 182 Cal. App. 3d 166, 175 83, 227 Cal. Rptr. 247, 252-57 (1986). The court rejected the Holmes court's substantive gloss on the factor of difference in choice of law rules, see infra text accompanying notes $136-47$, stating: 
sion is noteworthy in several respects. First, it declares that California forum non conveniens law diverges from the federal inodel. ${ }^{7}$ This declaration is important in itself, and it also poses the question of which articulation of forum non conveniens law should be applied by a California federal court sitting in diversity jurisdiction. ${ }^{8}$ Second, Holmes may have considerable practical impact in light of the proliferation of international

Under Califoruia law, the purpose of comparing the differences in conflict of law rules and the differences in substantive law which will be applied, once the choice of law has been made in each alteruative forum, is not simply to decide which forum would provide the most advantageous law from the viewpoint of the plaintiff. To the extent Holmes explicitly or implicitly directs otherwise, we decline to follow it.

Id. at 178, $227 \mathrm{Cal}$. Rptr. at 253. Elsewhere, however, the court recognized the Holmes decision's "substantive law analysis approach." Id. at 183, 227 Cal. Rptr. at 257. The court did not go so far as to endorse the substantial weight the Holmes court attached to the possibility of an unfavorable change in law, see infra text accompanying notes 124-47. The court wrote, "In Holmes . . . the court discussed the substantial disadvantage to plaintiffs if they were required to proceed under British law, ... conclud[ing] that Britain was not a 'suitable' alteruative forum. . . . Although the casc [at bench] cannot turn on this disadvantage in different substantive law, we may permissibly consider it." Id. at 182, 227 Cal. Rptr. at 256-57.

7. Holmes, $156 \mathrm{Cal}$. App. $3 \mathrm{~d}$ at 382,202 Cal. Rptr. at 779.

8. The Supreme Court has nevcr directly considered whether a federal court sitting in diversity should apply state or federal forum non conveniens doctrine under the Rules of Decision Act, 28 U.S.C. $\S 1652$ (1982), and Erie R.R. v. Tompkins, 304 U.S. 64 (1938). In several cases, the court has been able to avoid the issue by assuming that state and federal doctrine were identical. Piper Aircraft Co. v. Reyno, 454 U.S. 235, 248 n.13 (1981); Gulf Oil Corp. v. Gilbert, 330 U.S. 501, 509 (1947); Koster v. Lumbermens Mut. Casualty Co., 330 U.S. 518, 529 (1947). The Holmes decision's explicit declaration of the divergence between federal and California forum non conveniens law revives this unresolved question.

Whether state forum non conveniens law should apply in federal court under the Erie doctrine depends in large part on the purposes forum non conveniens is serving. Erie requires that a federal court sitting in diversity apply the substantive law of the state in which it is located. Under the Holmes decision, which stresses the policy of using forum non conveniens to vindicate substantive legislative intcrests, see infra text accompanying notes 26-31, a district court sitting in diversity almost certainly should apply state forum non conveniens law. Moreover, a substantive approach by definition recognizes that a forum non conveniens decision is outcome determinative in the sense that it is likely to influence a litigant's choice of forum. See Hanna v. Plumer, 380 U.S. 460, 467-68 (1965). Thus, the Erie doctrime would extend to this kind of substantive decision about governmental interests. See Stein, Forum Non Conveniens and the Redundancy of Court-Access Doctrine, 133 U. PA. L. REv. 781, 820 (1985). Contra Sibaja v. Dow Chem. Co., 757 F.2d 1215 (11th Cir. 1985) (Erie does not require the application of state forum non conveniens law, since the forum non conveniens doctrine is a rule of venue, not a rule of decision).

It also could be argned that regardless of the policies the doctrine is supposed to serve, a federal court should apply state forum non conveniens law under an outcome-determinative analysis. A frequent effect of granting a forum non conveniens motion, under any court's analysis, is that the case is decided under a diffcrent substantive law. If a federal court could dismiss a case that the state court would retain, then the " 'aceident' of federal diversity jurisdiction" would enable a party to "achieve a result in federal court which could not have been achieved in the courts of the Statc where the action was filed." Van Dusen v. Barrack, 376 U.S. 612, 638 (1964); see infra note 165. See also Comment, Forum Non Conveniens, A New Federal Doctrine, 56 YALE L.J. 1234, 1248 (1947). But see, Greenberg, The Appropriate Source of Law for Forum Non Conveniens Decisions in International Cases: A Proposal for the Development of Federal Common Law, forthcoming in 4 INT'L TAX \& BUs. LAw. 155 (1986) (arguing for the adoption of a federal common law of forum non conveniens applicable in both federal and state court where necessary to protect the federal interest in an effective foreign policy). 
product liability litigation, ${ }^{9}$ especially since foruin non conveniens disputes often are driven by differences in the substantive law of the forums. ${ }^{10}$ Finally, Holmes inay be a liarbinger of a substantively driven forum non conveniens doctrine that contrasts sharply with the privatelaw regulatory view that Piper indicates is held by the Supreme Court. It therefore invites reevaluation of the appropriate role of clroice of law considerations in forum non conveniens decisions.

The first part of this Comment explores the pohicies behind the forun non converiens doctrine and discusses relevant federal and Cahfornia legal background. Part II analyzes the clrange in doctrine announced in the Holmes decision against the background of California precedent. Part III suggests that the Holmes decision applies a substantive model of foruin non conveniens, and explores the inerits of that approach. It concludes that foruin non convemiens sliould incorporate substantive concerns, but that, even under a substantive model, the doctrine norinally should not take account of the possibility of an unfavorable cliange in law.

\section{LEGAL BACKGROUND}

\section{A. Origins and Policies of Forum Non Conveniens}

The doctrine of forum non conveniens originated in equity as a gradually expanding exception to the requirement that a court take jurisdiction where jurisdiction was properly laid. ${ }^{11}$ Perhaps in part because it

9. See Note, Forum Non Conveniens and Foreign Plaintiffs in the Federal Courts, 69 Geo. L.J. 1257, 1278 (1981).

10. See Comment, Forum Non Conveniens and American Plaintiffs in the Federal Courts, $47 \mathrm{U}$. CHI. L. REv. 373, 384 n.65 (1980) (citing cases). The practice of forum shopping to try a case before a more sympathetic jury or in a forum that features a more.favorable substantive law was one of the factors that prompted the development of the forum non conveniens doctrine. Stimson, Limitations on the Exercise of Jurisdiction in Personam, 10 Hastings L.J. 139, 142 (1958).

A possible indication of the impact in Califoruia of the Holmes decision is the class action suit filed shortly after Holmes on behalf of 26,000 victims of the chemical leak in Union Carbide's Bhopal plant. Simhal v. Union Carbide Corp., No. 833-433, (Cal. Super. Ct. San Francisco County, filed Dec. 21, 1984). This case was later consolidated with the action in the Southern District of New York. In re Union Carbide Corp. Gas Plant Disaster, 634 F. Supp. 842 (S.D.N.Y. 1986).

11. Forum non conveniens thus began as a jurisdictional concept. The doctrine has its origins in several Scottish cases in the nineteenth century, which used the term "forum non competens" to dismiss cases "both where the court lacked jurisdiction and where it was not expedient for the due administration of justice to hear the case." Barrett, The Doctrine of Forum Non Conveniens, 35 CALIF. L. Rev. 380, 387 n.35 (1947) (citing cases); see Comment, The Inconvenient Federal Forum, 60 HARV. L. REv. 908, 909 (1947). An embryonic version of the doctrine first appeared in Ainerican law as early as 1801. E.g., Willendson v. Forsoket, 29 F. Cas. 1283, 1284 (D. Pa. 1801) (No. 17,682). Federal admiralty courts used it to decline jurisdiction over suits between foreigners. See Comment, supra note 10, at 375. The use of the doctrine in such cases was approved by the United States Supreme Court in 1885. The Belgenland, 114 U.S. 355, 364-65 (1885). Gradually, the doctrine was applied in other narrowly defined arcas of litigation, such as suits between aliens and 
developed as an exceptional and discretionary equitable remedy, the contours of the doctrine often have been unclear. Forum non conveniens has meant many things to many courts. ${ }^{12}$ From the inception of the doctrine, commentators have remarked on the courts' confusion as to what makes a forum appropriate and on the poor predictability in the doctrine's application. ${ }^{13}$

A major source of this ambiguity is that courts have woven together in their application of forum non converiens at least three different policy rationales for the doctrine. ${ }^{14}$ First, there is convemence to the litigants. The central concern here is that the defendant sliould not be forced to litigate in the plaintiff's chosen forum when an alternative forum would be mucli more convemient. A second policy is convenience to the courts. The goal of this policy is to allocate the forum state's judicial resources so as to avoid adjudication of essentially imported controversies. Fimally, a few courts, like the court in Holmes, have come at least implicitly to consider whether the state has a substantive interest in the outcome of the litigation.

\section{Convenience to the Parties}

The policy of convemience to the parties focuses on sheer efficiency concerns - as between two forums, which will minimize the parties' outlay of time and money? Litigation can present a number of practical problems, sucli as access to evidence and cost of obtaiming witnesses, that can inake trial more or less "easy, expeditious and inexpensive."15 An impartial trial court miglit be the most fair and effective arbiter of when the burdens on the defendant are so great that they should be reallocated by a change in venue. ${ }^{16}$

Courts that focus on this policy refer to factors such as "balancing of convemences" and "relative ease of access to proof."17 Battles about

suits involving the internal affairs of foreign corporations. See generally Coininent, supra, at 921-24. It gained broader currency after its recognition in a 1929 law review article. See Blair, The Doctrine of Forum Non Conveniens in Anglo-American Law, 29 Colum. L. REv. 1 (1929). The modern law of forum non conveniens has developed in part in response to changes in the law of personal jurisdiction, which have exposed defendants to potential hardship and contributed to an enormous increase in judicial busmess. See Stein, supra note 8, at 803-05. (1947).

12. See Coininent, Forum Non Conveniens, A New Federal Doctrine, 56 YALE L.J. 1234, 1234

13. Id. at 1247. Ehrenzweig referred to "the chaos of forum non conveniens" in a much-cited critique. See Note, The Convenient Forum Abroad, 20 STAN. L. REV. 57, 58 n.4 (1967). See also Schlesinger, Methods of Progress in Conflicts of Laws-Some Comments on Ehrenzweig's Treatment of "Transient" Jurisdiction, 9 J. PuB. L. 313, 323-24 (1960) ("[T] here has been a complete failure to develop a reliable standard."); Barrett, supra note 11 , at 402 \& n.112.

14. See generally Barrett, supra note 11, at 404-09.

15. Gulf Oil Corp. v. Gilbert, 330 U.S. 501, 508 (1947).

16. See Comment, supra note 11 , at 931.

17. See id. 
these factors tend to be especially keen in international product liability cases, in which the defendant often is subject to jurisdiction in forums oceans removed from the place of injury and much of the evidence. The strongest and inost influential modern articulation of this policy appears in Piper Aircraft Co. v. Reyno. ${ }^{18}$ In holding that the possibility of an unfavorable cliange in law should not be given conclusive or even substantial weiglit in a forum non convemiens motion, the Supreme Court stated that "the central purpose of any forum non conveniens inquiry is to ensure that the trial is convenient." 19

\section{Convenience to the Courts}

Another focal point for the forum non convemens inquiry is convenience to the courts. Here, the efficient allocation of resources is again the concern, but judicial rather than private resources are weighed in the balance. Some of the "public-imterest factors" listed by the Supreme Court in Gulf Oil Corp. v. Gilbert ${ }^{20}$ reflect this policy. For example, the "appropriateness ... in having the trial ... im a forum that is at honie with the state law that inust govern the case, rather than having a court im some other forum untangle problems in conflict of laws,"21 is a factor focusing on efficient allocation of judicial resources, simce complicated conflict of laws imquiries generally will not pose problems of convenience to the hitigants.

Similarly, courts have a strong convemience interest in avoiding undue congestion in their dockets, smce "[a]dministrative difficulties follow for courts when litigation is piled up im congested centers instead of being handled at its origin."22 Conversely, the "local interest in having localized controversies decided at hoine"23 inay be rationalized under a convenience to the courts policy. ${ }^{24}$

18. 454 U.S. 235 (1981); see infra text accompanying notes 48-56; Paim v. United Technologies Corp., 637 F.2d 775, 797 (D.C. Cir. 1980), cert. denied, 454 U.S. 1128 (1981).

19. Piper, 454 U.S at 256. Although this statement on its face need not refer to the parties' convenience, the Piper opiniou at this point cites to two sources that clearly focus on that policy. See Pain v. United Technologies Corp., 637 F.2d 775, 797 (D.C. Cir. 1980) ("At best citizenship serves as an inadequate proxy for the American residence of plaintiff, which in turn is only one indicator of how inconvenient it may be for the plaintiff to litigate his case in a foreign forum, as neasured by the Gilbert factors of private interest.") (emphasis added) (footnote omitted), cert. denied, 454 U.S. 1128 (1981); Comment, supra note 10, at 382-83 (" $[I] t$ is undoubtedly true that American citizens, taken as a class, tend to possess characteristics that make foreign litigation inconvenient for them. It is entirely proper that such characteristics be weighed in a court's balancing of the parties' inconveniences.") (emphasis added) (footnote omitted).

20. 330 U.S. 501, 508-09 (1947); see also infra text accompanying notes 40-47.

21. Gulf Oil, 330 U.S. at 509.

22. Id. at 508 .

23. Id. at 509 .

24. But see text accompanying notes $153-73$ (arguing that this factor necessarily implicates substantive concerns). 
The convenience to the courts policy helps explain why sonie trial courts are enipowered to raise the forun1 non conveniens motion sua sponte. Section 410.30 of the Califoruia Code of Civil Procedure, for example, provides that a court can entertam the forum non conveniens issue upon the "nıotion of a party or its own niotion."25 If convenience to the parties were the sole policy enibodied in forun non conveniens doctrine, judicial initiation would be inapposite.

\section{Substantive Legislative Interests of the Forum}

A third policy that also could aniniate the forum non conveniens doctrine is the substantive legislative policies of the forun. By applying an analysis similar to that eniployed in sonie choice of law inquiries, forum non conveniens could focus on whether the forum has a sufficient interest in the litigation to justify retaining jurisdiction. ${ }^{26}$ Courts applymg this policy would consider not only convenience to the courts and the parties, but also whether the forum in its legislative policies has expressed an interest $\mathrm{n} 1$ controlling the type of conduct at issue. This approach suggests an alternative interpretation of the Suprenie Court's statement that " $[t]$ here is a local interest in having localized controversies decided at home."27

This policy is not prominent in current articulations of the doctrine. It has been at most implicit in forum non conveniens law, but it has played a role in some jurisdictions. ${ }^{28}$ For exanıle, New York courts historically refused to grant forum non conveniens niotions in conımercial cases, even when the plaintiff was a nonresident and the defendant could sliow serious inconvenience. ${ }^{29}$ The rationale for this rule was that the state had an mterest in encouraging coinmercial activity and growth by ensuring commercial entities the use of its courts. ${ }^{30}$ This interest

25. CAl. Civ. Proc. Code $\S 410.30$ (West 1973).

26. "Interest" here refers to the idea of a governmental interest developed by Brainerd Currie. Currie proposed a two step analysis for whether a government has an interest in the application of its law in a given case. First, the court construes and interprets the forum's law to determine what social, economic, or administrative governmental policy it expresses. Second, the court analyzes the state's relationship to the litigation to determine whether application of the state's law can rcasonably be expected to effectuate the policy. If it can, the state is said to have an interest in the applieation of its law. See, e.g., Currie, The Constitution and the Choice of Law: Governmental Interests and the Judicial Function, 26 U. CHI. L. REV. 9, 9-10 (1958); see also Currie, Married Women's Contracts: A Study in Confict-of-Laws Method, 25 U. CHI. L. REv. 227 (1958) [hereinafter Currie, Married Women's Contracts]. Cf. Greenberg, supra note 8, at 183 n.231 (urging a broader formulation of governmental interest, embracing the sensitivities and dignity of a nation, in the context of forum non conveniens decisions in international cases).

27. Gulf Oil Corp. v. Gilbert, 330 U.S. 501, 509 (1947).

28. See notes 69-74 and accompanying text.

29. Barrett, supra note 11, at 405 (citing cases).

30. Id. 
barred a forunı non conveniens dismissal even when it would have been appropriate in a tort cause of action arising out of similar facts.

A more pronounced exaniple of a substantively driven foruin non conveniens doctrine is provided by the Holmes court, which anchored its holding on California's substantive regulatory "interest in regulating the foreign niarketing of defective products developed here."31 The decision thus einphasized the foruin's interest in the apphication of a specified substantive pohicy, not just its interest in providing a forum for certain kinds of plaintiffs. Under this rationale, a court applying foruin non conveniens law nuust consider the forum's interest in the apphication of its law.

\section{Factors Sounding Under Different Policies}

Solne factors considered in the forum non convernens inquiry inay serve nore than one of these pohicies, $m$ which case the interpretation of the factor inay depend upon which policy the court is einphasizing. For exanıple, nıany jurisdictions, including California, ${ }^{32}$ will not grant a forunı non conveniens dismissal against a resident plaintiff. Under a convenience to the parties approach, courts may see residency as ensuring that the hitigation is convenient for at least one party. ${ }^{33}$ Under a convenience to the courts approach, they could conclude as a matter of allocation of finite judicial resources that residents should have priority of access to foruns in their own state. This priority arguably is independent of any interest $\mathrm{n} 1$ vindication of the forum's substantive interests and alnounts to a recognition that a primary role of courts is to provide local citizens with a forum for redress of their complaints. ${ }^{34}$ Finally, under a substantive approach, the state might be seen as having an overriding interest in ensuring that the disputes involving its residents are resolved in accordance with the substantive pohicies of the state.

Similarly, the policy of not imposing jury duty "upon the people of a community which has no relation to the litigation"35 may express a convenience to the courts concern for not squandering jury service on

31. 156 Cal. App. 3d 372, 391, 202 Cal. Rptr. 773, 788 (1984). See infra note 95.

32. See infra text accompanying notes 65-68.

33. See Piper Aircraft Co. v. Reyno, 454 U.S. 235, 255-56 ("When the home forum has been chosen, it is reasonable to assume that this choice is convenient."); Coinment, supra note 10, at 381 ("The plaintiff's citizenship may perhaps be a good proxy for his convenience; all other things being equal, one inight well suppose that an American citizen can sue inore conveniently at home than abroad.").

34. Thus, California courts have reasoned that since California residents support the judicial system, the state has a strong interest in assuring its citizens are not denied compensation as a result of the inconvenience and expense of bringing suit in a distant forum. Ryan \& Berger, Forum Non Conveniens in California, 1 PAC. L.J. 532, 547 (1970) (citing Thoonson v. Continental Ins. Co., 66 Cal. 2d 738, 427 P.2d 765, 59 Cal. Rptr. 101 (1967)).

35. Gulf Oil, 330 U.S. at $508-09$. 
imported controversies. It also can be integrated with a substantive approach, however, since it prescribes a sensitivity to those fact patterns that implicate a forum's interest in the application of its substantive policies.

The forum non conveniens decisions that focus on abuse of process ${ }^{36}$ also allow for varying interpretations. If a plaintiff has "resort[ed] to a strategy of forcing the trial at a most inconvenient place for an adversary, even at some inconvenience to himself," 37 then it may be important to decline jurisdiction to provide for the parties' convemence. Refusal to sanction abuses of process, however, also implicates the courts' interest in procedural integrity and efficient allocation of judicial resources.

\section{B. Federal Law}

The development and current status of federal forum non conveniens law are reflected in the two Supreme Court decisions that dominate the field: Gulf Oil Corp. v. Gilbert ${ }^{38}$ and Piper Aircraft Co. v. Reyno. ${ }^{39}$

\section{Gulf Oil Corp. v. Gilbert}

The Supreme Conrt's first authoritative statement of the forum non conveniens doctrine occurred in Gulf Oil Corp. v. Gilbert. ${ }^{40}$ The plaintiffs in Gulf Oil brought a diversity suit in the Southern District of New York alleging the negligent burning of a warehouse in Virginia. ${ }^{41}$ The Court held that the trial court had not abused its discretion in granting a forum non conveniens dismissal. ${ }^{42}$ While the Court specifically declined to catalog the circumstances that would justify exercise of the doctrine, ${ }^{43}$ it did formulate what lias become a well-known list of two sets of factors: private-interest factors and public-interest factors. ${ }^{44}$ The private-interest factors comprised "relative ease of access to sources of proof; availability

36. See Comment, supra note 11, at 930-31; see also Comment, supra note 10, at 376. Courts focusing on abuse of process speak in terms of "imposition on the court's jurisdiction," "oppression," or "harassment." Id. The English conception of the doctrine apparently relied heavily on the idea of abuse of process. Comment, supra note 11, at 911.

37. Gulf Oil, 330 U.S. at 507.

38. 330 U.S. 501 (1947).

39. 454 U.S. 235 (1981).

40. 330 U.S. at 504. The plaintiff in Gulf Oil was a Virginian, the defendant was doing busimess in Virgima, the alleged tort occurred in Virginia, and nearly all the evidence was in Virginia. See Comment, supra note 10, at 375. Gulf Oil was decided in conjunction with Koster v. Lumbermens Mut. Casualty Co., 330 U.S. 518 (1947), which stressed the propriety of a forum non conveniens dismissal when the plaintiff's choice of forum is so vexatious or oppressive to the defendant "as to be out of all proportion to plaintiff's convenience." Id. at 524 .

41. 330 U.S. at 502-03.

42. Id. at 512 .

43. Id. at 508 .

44. Id. 
of compulsory process for attendance of unwilling, and the cost of obtaining attendance of willing, witnesses; possibility of view of premises, if view would be appropriate to the action; and all other practical problems that make trial of a case easy, expeditious and mexpensive." 45 These factors are considered to ensure that the hitigation is convement for the parties.

The public-interest factors imphicitly focused on the forum's convenience interests. These included the mipropriety of imposing jury duty on members of a community that has no relation to the litigation and the "local interest in having localized controversies decided at hoine." 46 Another public-interest factor the Court considered was problems of conflict of laws. The focus here, however, was not on any possible unfairness to the plaintiff but rather on the practical burdens that a court might encounter if it had to "untangle probleins in conflict of laws, and in law foreign to itself." 47 That is, the Court was not concerned with the issue of which law was to apply in the controversy, but only with the possible procedural complications of inaking that determination.

\section{Forum Non Conveniens in an International Setting: Piper Aircraft Co. v. Reyno}

The Supreine Court refined federal foruin non conveniens doctrine in Piper Aircraft Co. v. Reyno. ${ }^{48}$ Piper was a wrongful deatl1 action initiated in a Califonria state court by a Califonina representative of the estates of five Scottisli citizens killed in an airplane crasl in Scotland. The defendants were the coinpany that had inanufactured the plane in Pennsylvania and the coinpany that liad nranufactured the plane's propellers in Ohio. After the defendants removed the case to federal court, the action was transferred to Pennsylvaina pursuant to 28 U.S.C. $\S 1404(a) .{ }^{49}$ After defendants agreed to submit to jurisdiction in Great

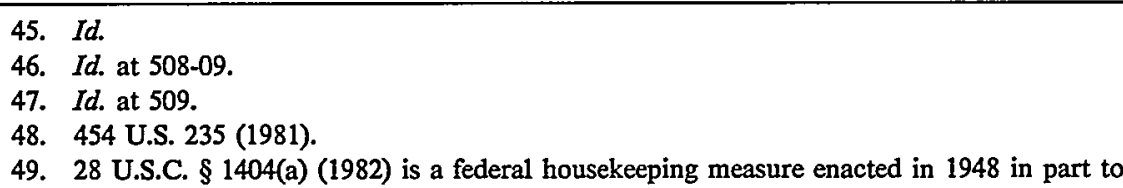
mitigate the potential harshness of a forum non conveniens dismissal. See Note, supra note 9 , at 1261 n.31; see also Harrison v. United Fruit Co., 141 F. Supp. 35, 36 (S.D.N.Y. 1956). The requirements for application of $\S 1404$ (a) are much less stringent than those for a forum non conveniens dismissal. See Ryan \& Berger, supra note 34, at 547. One corollary to the relative ease of transfer, at least where the defendant moves for a change of venue under $\S 1404$, is that "[a] change of venue under $\$ 1404$ (a) generally should be, with respect to state law, but a change of courtrooms." Van Dusen v. Barrack, 376 U.S. 612, 639 (1964). There is thus no change in applicable law upon a $\S 1404$ transfer.

The Holmes court placed great weight on the existence of $\S 1404(\mathrm{a})$, arguing that "federal courts ... have broader discretion to grant forum non converiens motions than do state courts, because of their authority to transfer venue to a federal court in another state rather than simply stay or dismiss the action." $156 \mathrm{Cal}$. App. 3d at 378, 202 Cal. Rptr. at 776. However, $§ 1404$ does not 
Britain and to waive the statute of limitations, the district court granted a forum non conveniens dismissal, holding that Scotland was the appropriate forum. ${ }^{50}$ The Court of Appeals for the Third Circuit reversed. It held that dismissal was barred autoniatically where a change of forum would produce a change in applicable law. ${ }^{51}$

The Supreme Court reversed, deciding that the district court had not abused its discretion in dismissing the action. The core of the Court's holding was that the possibility of an unfavorable change in law should not be given conclusive or even substantial weight in the forum non conveniens inquiry, unless the remedy in the alternative forun is so inadequate as to be no remedy at all..$^{52}$ The Court wrote:

In fact, if conclusive or substantial weight were given to the possibility of a change in law, the forum non conveniens doctrine would become virtually useless. Jurisdiction and venue requirements are often easily satisfied. As a result, many plaintiffs are able to choose from among several forums. Ordinarily, these plaintiffs will select that forum whose choiceof-law rules are most advantageous. Thus, if the possibility of an unfavorable change in substantive law is given substantial weight in the forum non conveniens inquiry, dismissal would rarely be proper. ${ }^{53}$

The Court also held that a foreign plaintiff's choice of forum merits less deference than the choice of an American plaintiff. ${ }^{54}$ The Court reasoned that the normal deference for an American citizen's choice hinges on an assuniption that the choice is convenient. "When the plaintiff is foreign, however, this assumption is much less reasonable. Because the central purpose of any forum non conveniens inquiry is to ensure that the trial is convenient, a foreign plaintiff's choice deserves less deference." 55 Under this reasoning, a resident plaintiff's choice of forun nuerits deference, but ouly because it indicates that the trial alnost certainly will be convenient for at least one party. The same presuniption does not extend to the choice of a foreign plaintiff. This distinction between foreign and resident plaintiffs underscores that in federal forun non conveniens law, no particular significance adheres to a change in substantive law; it assumes importance only when it is so extrenie as to affect the predicate

authorize transfer to a foreign forum. Thus, in an international setting, the existence of $\S 1404$ (a) cannot justify a differeut forum non conveniens calculus for state as compared with federal courts. See also infra note 165 (arguing that Van Dusen provides implieit support for a substantive model of fornm non conveniens).

50. Reyno v. Piper Aircraft Co., 479 F. Supp. 727, 737-38 (M.D. Pa. 1979), rev'd, 630 F.2d 149

(3d Cir. 1980), rev'd, 454 U.S. 235 (1981).

51. Reyno v. Piper Aircraft Co., 630 F.2d 149, 164 (3d Cir. 1980), rev'd, 454 U.S. 235 (1981).

52. Piper, 454 U.S. at 247-51, 255.

53. Id. at 250 .

54. Id. at 256 .

55. Id. at 256; see also Pain v. United Technologies Corp., 637 F.2d 775, 797-98 (D.C. Cir. 1980), cert. denied, 454 U.S. 1128 (1981). 
inquiry into the existence of an alternative forum. Therefore, " $[t]$ he possibility of a change in substantive law should ordinarily not be given conclusive or even substantial weight in the forum non conveniens inquiry."56

\section{California Law}

The forum non conveniens doctrine was recognized by name in California in Price v. Atchison, Topeka \& Santa Fe Railway. ${ }^{57}$ In its first articulation of the doctrine, the Califorina Supreme Court rehed almost exclusively on the list of factors froin Gulf Oil. This indicates that at its birth Califorina forum non conveniens law was seen as substantially similar to its federal counterpart. ${ }^{58}$

The Califorina doctrine of forum non conveniens soon becaine encuinbered by a nuultitude of judicially recognized factors. ${ }^{59}$ Moreover, although the doctrine was codifed in $1970,{ }^{60}$ subsequent judicial and scholastic elaboration have further coinplicated the law; ${ }^{61}$ a leading case

56. Piper, 454 U.S. at 247.

57. 42 Cal. 2d 577, 268 P.2d 457 (1954), cert. denied, 348 U.S. 839 (1954). In Price, the California Supreme Court affirmed the trial court's grant of a forum non conveniens motion in a Federal Employers' Liability Act action for personal mjuries sustained by the New Mexico plaintiff in New Mexico while he was working for the defendant railroad company, a Kansas corporation doing business in New Mexico and California. Id. at 586-87, 268 P.2d at 462-63.

58. The court's acceptance of forum non conveniens in California rested heavily on a convenieuce-to-courts rationale. See id. at 583-84, 268 P.2d at 461 (stressing the alleviation of the burden on courts and jurors as a consequence of adopting the forum non converiens doctrine).

59. See Barrett, supra note 11, at 402 .

60. Cal. Civ. Proc. CoDE $\S 410.30$ (West 1973). Section 410.30 was meant neither to enlarge nor to restrict the scope of forum non conveniens as it had been developed in the courts. Subsection (a) provides:

When a court upon motion of a party or its own motion finds that in the interests of substantial justice an action should be heard in a forum outside this state, the court shall stay or dismiss the action in whole or in part on any conditions that may be just.

Id. The accompanying commentary instructs a court not to entertain a suit "if it believes that the forum of filing is a seriously inconvenient forum for the trial of the action." Id., Judicial Council comment at 490 . The commentary goes on to list several factors culled from various sources, principally the Gulf Oil decision. It continues with the passage that strongly impressed the Holmes court, in which it states that the two most important factors favoring retention of jurisdiction are: (1) not disturbing the plaintiff's choice of forum except for weighty reasons, and (2) not dismissing unless a suitable alternative forum is available. Id. at 492.

Arguably, neither of these factors should be part of the forum non conveniens inquiry proper. The second is best seen as a factual precondition to entertaining a forum non conveniens motion. The first may be merely an expression of an allocation of burden of proof in a forum non conveniens motion. See infra text accompanying notes 99-147.

61. See, e.g., Ryan \& Berger, supra note 34 , at 540 for a typical potpourri of relevant factors. The Holmes court culled factors from ten California cases in its analysis, citing Archibald v. Cineraina Hotels, 15 Cal. 3d 853, 544 P.2d 947, 126 Cal. Rptr. 811 (1976); Price v. Atchison, Topeka \& Santa Fe Railway, 42 Cal. 2d 577, 268 P.2d 457 (1954); Dendy v. MGM Grand Hotels Inc., 137 Cal. App. 3d 457, 187 Cal. Rptr. 95 (1982); Hemmelgarn v. Boeing Co., 106 Cal. App. 3d 576, 165 Cal. Rptr. 190 (1980); Interuational Harvester Co. v. Superior Court, 95 Cal. App. 3d 652, 157 Cal. Rptr. 324 (1979); Jagger v. Superior Court, 96 Cal. App. 3d 579, 158 Cal. Rptr. 163 (1979); Henderson v. Superior Court, 77 Cal. App. 3d 583, 142 Cal. Rptr. 478 (1978); Brown v. Clorox Co., 
hists no fewer than twenty-five factors that a California court should consider in a forum non conveniens notion. ${ }^{62}$ As a result, California doctrine is unwieldy, and commentators have reniarked on its questionable predictive value. ${ }^{63}$

Nevertheless, the cases reveal distinctive tendencies in California forun non conveniens law. First, California courts distinguish between resident and nonresident plaintiffs, refusing to grant forun 1 non conveniens dismissals against bona fide resident plaintiffs. Second, California places great weight on whether or not a corporate defendant nuaintains its principal place of business in California. Third, sonıe Califorina cases focus at least implicitly on whether the forum has an interest in the application of its substantive policies.

California courts have insisted on the distinction between resident and nonresident plaintiffs in the forum non conveniens analysis from the time the doctrine was first recognized in Price. The Price court concluded that when exercising its discretionary power to dismiss, the court constitutionally could distinguish between residents and nonresidents. ${ }^{64}$ The distmction was critical again in Archibald v. Cinerama Hotels, ${ }^{65}$ the California Suprene Court's niost recent consideration of the forun non conveniens doctrine. Archibald was a class action brought by California residents against Hawaii lotel and motel operators, allegiug a discrininatory rate structure. The suprenie court reversed as an abuse of discretion the trial court's grant of a forum non conveniens disnissal, holding that a forum non conveniens dismissal is improper in California when the plaintiff is a California resident unless California cannot provide an adequate forum. ${ }^{66} \mathrm{~A}$ California trial court may stay the action in response to a forum non conveniens motion against a bona fide ${ }^{67}$ California resident, but it may not dismiss, even if the alternative forun is nuch inore

56 Cal. App. 3d 306, 128 Cal. Rptr. 385 (1976); Chavarria v. Superior Court, 40 Cal. App. 3d 1073, 115 Cal. Rptr. 549 (1974); Great N. Ry. v. Superior Court, 12 Cal. App. 3d 105, 90 Cal. Rptr. 461 (1970), cert denied, 401 U.S. 1013 (1971).

62. Great N. Ry. v. Superior Court, 12 Cal. App. 3d 105, 90 Cal. Rptr. 461 (1970), cert. denied, 401 U.S. 1013 (1971).

63. See Comment, Open Questions in California's Adoption of the Doctrine of Forum Non Conveniens, 42 CALIF. L. REv. 690, 692 (1954) (Gulf Oil factors are very vague principles that provide inadequate guidance for California courts); see also Barrett, supra note 11, at 402 (noting the lower predictability arising from the many factors which make up the forum non conveniens doctrine).

64. $42 \mathrm{Cal} .2 \mathrm{~d}$ at $582-83,268 \mathrm{P} .2 \mathrm{~d}$ at 460 (" 'There are manifest reasons for preferring residents in access to often overcrowded Courts, both in convenience and in the fact that broadly speaking it is they who pay for maintaining the Courts concerned." "' (quoting Douglas v. New York, N.H. \& H. R.R., 279 U.S. 377,387 (1929))).

65. 15 Cal. 3d 853, 544 P.2d 947, 126 Cal. Rptr. 811 (1976).

66. Id. at 859,544 P.2d at 951,126 Cal. Rptr. at 815 .

67. The Archibald court acknowledged an exception where the nominal plaintiff is appointed as a representative of a nonresident real party in interest in order to gain access to California courts. Id. at 859 \& n.6, 544 P.2d at $951 \&$ n.6, 126 Cal. Rptr. at 815 \& n.6. 


\section{convenient. $^{68}$}

Both the importance of a corporate defendant's principal place of business and the tendency of some California courts to take account of the state's substantive interests can be demonstrated by comparing Great Northern Railway v. Superior Court ${ }^{69}$ with Brown v. Clorox Co. ${ }^{70}$ In Great Northern, a nonresident real party in interest sued a defendant domg business in California on a claim arising out of a Washington accident. $^{71}$ The court held that the trial court had abused its discretion by denying a forum non conveniens dismissal . Brown, by contrast, involved a nonresident plaintiff sunig a defendant with its principal place of business in California on a claim arising out of an accident in Washington. ${ }^{72}$ The court there held that the trial court had abused its discretion by granting a forum non conveniens dismissal. The two cases thus deniarcate one set of boundaries on a California trial court's discretion defined by whether the defendant had its prinicipal place of business in California. $^{73}$

This emphasis on the defendant's prinicipal place of busmess could be explamed under either a convenience to the parties or a convenience to the courts approach. The court in Brown, however, used it to ground an argument based upon the state's substantive legislative interest. The court concluded that since two of the three defendants were California corporations, California had a regulatory interest in "the manufacturnig, ... packaging, ... distributing, and selling of products in [California] and sendimg those products from this state to other states."74 This fac-

68. Id. at $858-60,544$ P.2d at $950-52,126 \mathrm{Cal}$. Rptr. at $814-16$. By implication, a forum non conveniens dismissal could be appropriate against a nonresident plaintiff when the alternative forum is much more convenient.

It is wortlı stressing that the Archibald principle is less a part of the forum non conveniens calculus than an exception to it. Archibald loolds that the entire inquiry is moot where tlie plaintiff is a California resident.

69. 12 Cal. App. 3d 105, 90 Cal. Rptr. 461 (1970), cert. denied, 401 U.S. 1013 (1971).

70. 56 Cal. App. 3d 306, 128 Cal. Rptr. 385 (1976).

71. 12 Cal. App. 3d at 107-08, 90 Cal. Rptr. at 463.

72. In Brown, an infant in Washington was injured by drinking some Liquid-plumr that was bouglit in Waslington. The product's place of manufacture was uncertain. 56 Cal. App. 3d at 30809, 128 Cal. Rptr. at 388.

73. See also Appalacliian Ins. Co. v. Superior Court, 162 Cal. App. 3d 427, 437 n.3, 208 Cal. Rptr. 627, 632 n.3 (1984) (possible difference in forum non conveniens inquiry if a litigant not only conducted substantial busmess in the state but also liad its principal place of busimess tliere).

74. $56 \mathrm{Cal}$. App. 3d at 313, $128 \mathrm{Cal}$. Rptr. at 391. The Holmes court was more direct. "This state has an interest in regulating the foreign marketimg of defective products alleged to have been developed in California." 156 Cal. App. 3d at 389, 128 Cal. Rptr. at 784. See also Hemmelgarn v. Boeing Co., 106 Cal. App. 3d 576, 580, 165 Cal. Rptr. 190, 192 (1980) ("Even wliere tlie plaintiff is out of state, but willing to slioulder tlie burden of mconvenience and additional expense of litigation in California, the motion to dismiss should be denied if plaintiff claims defendants are companies incorporated in California, maintain their principal place of business liere, and conduct themselves 
toring-in of California's interest foreshadowed a more pronounced substantive approach in the Holmes case.

II.

\section{California Forum Non Conveniens Doctrine Under HOLMES V. SYNTEX LABORATORIES, INC.}

\section{A. The Holmes Case}

Holmes v. Syntex Laboratories, Inc. ${ }^{75}$ was one of a series of cases filed on behalf of British women allegedly injured as a result of using the oral contraceptive Norinyl. ${ }^{76}$ The defendant, Syntex Laboratories, was a Delaware corporation with its principal place of business in California. ${ }^{77}$ The plaintiff alleged that Syntex "caused and allowed" Norinyl to be distributed and marketed in England without adequate warning of its possible dangerous side effects. ${ }^{78}$

The defendants inoved to dismiss the coinplaint on foruin non conveniens grounds and agreed to submit to the jurisdiction of the British courts and waive any statute of limitations defense if the inotion were granted. ${ }^{79}$ The trial court, relying heavily on the United States Supreme Court decision in Piper Aircraft Co. v. Reyno, ${ }^{80}$ granted the inotion. ${ }^{81}$

The court of appeal reversed. While it agreed that Cahifornia forum non convemiens law derived from federal law, ${ }^{82}$ it held that the doctrine

here so as to cause injuries to others in another state." (citing Brown, 56 Cal. App. 3d at 313, 128 Cal. Rptr. at 385)).

Note that California had a clearer connection to the litigation in Brown than in Holmes, since two of the Brown defendants were California corporations and the defendants in Brown actually manufactured, packaged, and distributed the harmful products.

75. 156 Cal. App. 3d 372, 202 Cal. Rptr. 773 (1984).

76. See, e.g., Dowling v. Richardson-Merrell, Inc., 727 F.2d 608 (6th Cir. 1984); Harrison v. Wyeth Laboratories, 510 F. Supp. 1 (E.D. Pa. 1980), aff'd mem., 676 F.2d 685 (3d Cir. 1982); Jones v. Searle Laboratories, 93 Ill. 2d 366, 444 N.E.2d 157 (1982); Bewers v. Annerican Hoine Prods. Corp., 99 A.D.2d 949, 472 N.Y.S.2d 637 (1984), aff'd, 64 N.Y.2d 630, 474 N.E.2d, 485 N.Y.S.2d 39 (1984).

77. Holmes, $156 \mathrm{Cal}$. App. 3d at 376, $202 \mathrm{Cal}$. Rptr. at 775.

78. Id. The complaint presented causes of action for negligence, strict liability, breach of warranty, and fraud and inisrepresentation. Id. While the contraceptive apparently had been manufactured, marketed, and distributed in England by an independent subsidiary of Syntex not named in the complaint, the plaintiff alleged that the defendants had performed all premarketing research, chemical studies, animal studies, and clinical studies for Norinyl in California. Id. at 388, 202 Cal. Rptr. at 783.

After Syntex Laboratories moved for a forum non conveniens dismissal, the complaint was ainended to name both Syntex U.S.A., Inc. and Syntex Corporation. Syntex U.S.A. was a Delaware corporation with offices in Palo Alto. Syntex Corporation, a Panamanian corporation with offices in Palo Alto, was the parent of both Syntex Laboratories and Syntex U.S.A. Id. at 376.

79. Id. at 376-77, $202 \mathrm{Cal}$. Rptr at 775.

80. 454 U.S. 235 (1981).

81. See Holmes, 156 Cal. App. 3d at 376-77, 202 Cal. Rptr. at 775.

82. Id. at 378,202 Cal. Rptr. at 776. 
in California had come to diverge from its federal counterpart im two crucial respects. First, "the rule of substantial deference to the plaintiff's choice of forum has much greater importance" in California forum non convemens law than in federal law after Piper, even when the plaimtiff is a foreigner. ${ }^{83}$ Second, "California attaches far greater significance to the possibility of an unfavorable change in applicable law resulting from a forum non convemens dismissal." 84 The court held that because of the trial court's failure to give adequate weight to these two principles, its decision to dismiss was an abuse of discretion. ${ }^{85}$

The court identified the plaintiff's choice of forum and the possibility of an unfavorable change in law as the most important elements in the California calculus, ${ }^{86}$ implying that they were distimct from and paramount to the list of public-interest and private-interest factors set down by the United States Supreme Court in Gulf Oil Corp. v. Gilbert. ${ }^{87}$ "Having deternined that the California law of forum non convemens differs from federal law in two fundamental respects," 88 the court proceeded to consider the hist of twenty-five factors laid out in Great Northern Railway v. Superior Court. ${ }^{89}$ The court consolidated these factors into five factors it considered most important for the Holmes case: the existence of a suitable alternative forum; defendant's place of incorporation; the parties' relationships to California; the burden on California courts; and the relative convenience to the parties. ${ }^{90}$

The court then evaluated the case in light of each of the five factors. In appraising the availability of a suitable alternative forum, it used a novel approach. Stating that "in the law, theory and reality soinetimes diverge,"91 the court considered British negligence law in its actual application to product hability hitigation. ${ }^{92}$ The court was impressed by studies plaintiffs cited that indicated British neghigence law presented greater obstacles to recovery than American law. ${ }^{93}$ The court concluded:

If the present litigation occurs in Britain, appellants ... will be forced to litigate under a system of negligence law that the British themselves have condemned as inadequate in the field of defective products. The resulting disadvantage to appellants is a factor that constitutes denial of a "suitable" alternative forum under California law (though not, as required

83. Id. at 380-81, 202 Cal. Rptr. at 778 .

84. Id. at 381, 202 Cal. Rptr. at 778.

85. Id. at 391, 202 Cal. Rptr. at 785.

86. Id. at 378-79, 202 Cal. Rptr. at 776-77.

87. 330 U.S. 501 (1947).

88. Holmes, $156 \mathrm{Cal}$. App. $3 \mathrm{~d}$ at 382, $202 \mathrm{Cal}$. Rptr. at 779.

89. See id. at 378 n.2, 202 Cal. Rptr. at 776 n.2.

90. Holmes, $156 \mathrm{Cal}$. App. 3d at 383, 202 Cal. Rptr. at 780.

91. Id. at 385, $202 \mathrm{Cal}$. Rptr. at 781 .

92. Id. at 383-87, 202 Cal. Rptr. at 780-82.

93. Id. at 385, 202 Cal. Rptr. at 781. 
under federal law, a denial of "any" remedy under Piper) and weighs

heavily against a forum non convemens dismissal. ${ }^{94}$

To the next two questions-defendant's principal place of business and the parties' relationship to California-the Holmes court supplied essentially the same answer: it was not unfair to require corporate defendants to defend a complaint against them in the forum where they have their prinicipal place of busmess and where the tort allegedly was committed. 95

The Holmes court disposed of the last factor on its list-the relative convenience of the parties ${ }^{96}$-by noting that the brunt of the inconvenience fell on the plaimtiffs. That fact made the convenience issue of relatively little concern, smce the plaintiffs, "for tactical reasons, [had] elected to shoulder the burden of hitigating abroad."97 As a result, this factor too weighed against dismissal.

The court summarized its holding im its assessment of the burden to the trial court of retaining jurisdiction. It evaluated that burden in light of the state's perceived substantive interest in regulating the in-state conduct of corporations with their principal place of business in California. The court wrote:

The burden imposed on the trial court, while substantial, would not be unfair, imequitable or disproportionate in view of the defendants' relationship to and alleged conduct in this state and the state's interest in regulating the foreign marketing of defective products developed here. While we are sensitive to concerns of creating or adding to trial court backlogs, California courts have a responsibility to provide a forum for hitigation against corporations utilizmg this state as their principal place of business for torts committed in California. ${ }^{98}$

94. Id. at 387, $202 \mathrm{Cal}$. Rptr. at 782. The concurring opinion said explicitly that the trial court should have determined if British remedies for negligence would have been appropriate "in actual application." Id. at 392, 202 Cal. Rptr. at 786 (Low, P.J., concurring).

95. First, the court found that it was not unfair to require corporate defendants to defend a tort action in the forum where they have their principal place of business and where the tort allegedly was committed. Id. at $387,202 \mathrm{Cal}$. Rptr. at 783. Second, using somewhat circular reasoning, the court concluded that since the connection between the defendant and California imposed upon the defendant an obligation to participate in judicial proceedings in the state, a forum non conveniens dismissal would be mappropriate. Id. at 387-88, 202 Cal. Rptr. at 783. Third, the court determined that the burden on the California courts was not disproportionate given the connection of the parties to the cause of action, and that this connection raised California's "interest in regulating the foreign marketing of defective products alleged to have been developed in California." Id. at 389, 202 Cal. Rptr. at 784.

96. Cf. Piper Aircraft Co. v. Reyno, 454 U.S at 256. ("[T] he central purpose of any forum non conveniens inquiry is to ensure that the trial is convenient . ..."). See note 19, supra.

97. 156 Cal. App. 3d at 390, 202 Cal. Rptr. at 784.

98. Id. at 391, 202 Cal. Rptr. at 785. 


\section{B. Analysis of the Holmes Opinion}

This Section scrutinizes the Holmes opinion's use of doctrine and precedent. It argues that the Holmes court misconstrued doctrinal language in according substantial deference to the choice of a nonresident plaintiff. It then suggests the court mistakenly assumed that California law applied, but that in any event, its decision to factor the possibility of an unfavorable change of law into the forum non conveniens calculus was grounded in another faulty interpretation of doctrine.

As a preliminary inatter, the Holmes opinion probably unduly eniphasizes the divergence of federal and California forum non conveniens law. The emphasis is understandable, because under federal precedents, specifically Piper Aircraft Co. v. Reyno, ${ }^{99}$ a forum non conveniens dismissal might have been required in Holmes, and certainly would not have been an abuse of discretion. In fact, however, California cases and statutory law did not so clearly diverge from federal law before Holmes. To the contrary, they rehed heavily on federal precedent. ${ }^{100}$ To reach its conclusion, moreover, the Holmes court had to overlook prominent contrary opinion. The United States Supreme Court in 1 Piper perceived no divergence between federal and California forum non conveniens law, stating in a footnote, "California law on forum non conveniens disınissals [is] virtually identical to federal law."101 In fact, any clear spht between federal and California forum non conveniens law is a product of the Holmes decision itself.

\section{Deference to Plaintiff's Choice of Forum}

One of the Holmes court's two principal holdings was that "a foreign plaintiff's choice of forum is still afforded substantial deference im California." 102 That holding overlooks the iniplication of the distinction California courts have drawn between resident and nonresident plaimtiffs. It also gives independent weight to language properly viewed as an

99. 454 U.S. 235 (1981).

100. Indeed, the forum non conveniens case that probably has had the greatest influence on California law is that of the United States Supreme Court hi Gulf Oil Corp. v. Gilbert, 330 U.S. 501 (1947). Each of the cases cited by the Holmes court, as well as the Holmes opinion itself, cites approvingly to Gulf Oil. See, e.g., Archibald v. Cinerama Hotels, 15 Cal. 3d 853, 860, 544 P.2d 947, 952, 126 Cal. Rptr. 811, 816 (1976); Brown v. Clorox Co., 56 Cal. App. 3d 306, 310, 128 Cal. Rptr. 385, 388 (1976); Great N. Ry. v. Superior Court, 12 Cal. App. 3d 105, 109, 90 Cal. Rptr. 461, 464 (1970), cert. denied, 401 U.S. 1013 (1971); see also CAL. CIv. PROC. CoDE $§ 410.30$ Judicial Council conıment 490 (West 1973) (citing Gulf Oil as the first illustrative case).

101. Piper, 454 U.S. at 248 n.13. The Third Circuit appellate opinion in Piper, which the Holmes court cited as the proper federal analog to California law, $156 \mathrm{Cal}$. App. 3d at 380, $202 \mathrm{Cal}$. Rptr. at 777-78, shared the same assuniption. Reyno v. Piper Aircraft Co., 630 F.2d 149, 158 n.20. (3rd Cir. 1980) ("In all respects relevant to this case, then, we find no dissimilarities in the factors considered under federal and California law."), rev'd, 454 U.S. 235 (1981).

102. Holmes, 156 Cal. App. 3d at 382, 202 Cal. Rptr. at 779. 
expression of the allocation of burden of persuasion in a forum non conveniens motion rather than a part of the forum non conveniens inquiry proper.

Cases such as Price and Archibald that distinguish between resident and nonresident plaintiffs suggest that prior to Holmes, the mere fact that plaintiff had chosen a California forum merited no independent weight in the forum non convemiens calculus. ${ }^{103}$ Another California case, Great Northern Railway v. Superior Court, ${ }^{104}$ also contradicts the Holmes court's position. Great Northern was a wrongful death action arising out of a Washington resident's death in Washington. The defendant, a railroad with its prinicipal place of business in Minnesota, had some tracks in California. The decedent's widow hired a California law firn whose employee was appomted administratrix of the estate, thereby becoming the nominal plaintiff. ${ }^{105}$ The court of appeal held that the trial court's failure to grant a forum non conveniens dismissal had been an abuse of discretion, because the legitimate interests of the real party in interest were not served by trial in California. ${ }^{106}$ The court wrote that "[i]t is . . . estabhshed law that the principle of forum non conveniens will not ordinarily apply when the plaintiff is a resident of the state where the action is brought. . . . But that rule is wholly inapplicable where the plaintiff is the resident administrator of the estate of a nonresident decedent."107 Great Northern thus demonstrates that, before Holmes, California courts did not necessarily defer to the plaintiff's choice when the real party was a nonresident. ${ }^{108}$

In support of its contention that California law gave greater defer-

103. See supra notes 57-68 and accompanying text.

That California courts accord absolute deference to a resident plaintiff's choice of forum does not in itself preclude granting substantial deference to a nonresident plaintiff's choice. But the distmction among kinds of plaintiffs indicates that the courts do not perceive that a privileged status inheres in the mere act of filmg a complaint. Rather, it is the attributes of a particular plaintiff, such as residency, that make her choice worthy or not worthy of deference. See Greenberg, supra note 8, at 162 n.66.

104. 12 Cal. App. 3d 105, 90 Cal. Rptr. 461 (1970).

105. Id. at $108,90 \mathrm{Cal}$. Rptr. at 463.

106. Id. at $115,90 \mathrm{Cal}$. Rptr. at 468 .

107. Id. at $111,90 \mathrm{Cal}$. Rptr. at 465 (emphasis in original).

108. The court wrote:

'The administratrix] is merely the nominal plaintiff. Her residence in this District should have no weight in the scale which the Court must examine as to the equities which are presented on this motion, and upon which it must exercise its discretion. At the most, it would seem that her residence is a factor of relatively little consequence.'

Id. at 111, 90 Cal. Rptr. at 466 (quoting Giles v. Western Airlines, 73 F. Supp. 616, 617 (D. Minn. 1947)).

The Great Northern court further held it improper for a trial court to consider in a forum non conveniens motion the possibility that courts and juries in metropolitan areas might provide a larger recovery than in the alternative fornm. Id. at $112,90 \mathrm{Cal}$. Rptr. at 466 . Since the prospect of a larger recovery may motivate a fornm non conveniens dispute, this holding provides another argument against substantial deference to a plaintiff's choice as such. 
ence to a plaintiff's choice of forum than did federal law, the Holmes court cited passages from California cases ${ }^{109}$ all of which trace, iromically, to a proposition of federal law: the Supreme Court's statement in Gulf Oil that "unless the balance is strongly in favor of the defendant, the plaintiff's choice of a forum will rarely be disturbed." 110 This language inight suggest that courts of the plaintiff's chosen forum should give presumptive weight to the plaintiff's choice simply to honor the plaintiff's subjective preference that the case be heard there. However, case law and history suggest another interpretation.

The development of forum non convernens comcided with the expansion of a court's ability to exercise personal jurisdiction over defendants. ${ }^{11}$ Forum non conveniens was viewed as a device to limit this increased access. ${ }^{112}$ In part because the doctrine began as an equitable, extraordimary remedy, the trial court's discretion to disimiss was limited to cases where the balance of factors strongly favored the defendant. ${ }^{113}$ In hight of this history, the language fron1 Gulf Oil more logically expresses not sonie independent deference toward freedom of choice for those parties who file a complaint, but rather the idea that forum non conveniens is "by its nature a drastic rentedy to be exercised ... with caution and restraint." 114 That is, the language is a shorthand way of saying that forum non conveniens, which represents a judicial override of the legislature's decision to exercise jurisdiction, should be regarded as an extraordiniary renredy available only in limited circumstances, as for example when the defendant otherwise might be subjected to significant and unnecessary mconvenience and expense. ${ }^{115}$

109. Holmes, 156 Cal. App. 3d at 381, 202 Cal. Rptr. at 778.

110. Gulf Oil Corp. v. Gilbert, 330 U.S. 501, 508 (1947).

111. See Stein, supra note 8, at 801-04.

112. See Comment, supra note 12, at 1234.

113. See id. at 1235 . The caution with which the doctrine originally was circumscribed may be the result of a since-discredited theory that the right to sue in state courts was among the privileges granted to all United States citizens in the Privileges and Immunities Clause of the Constitution. See id. at 1235 \& n.10. Though this conception eroded, its prior influence may have encouraged caution in exercising the discretion allowed under the forum non conveniens doctrine.

114. Bechtel Corp. v. Industrial Indem. Co., 86 Cal. App. 3d 45, 49, 150 Cal. Rptr. 29, 31 (1978).

115. Ryan \& Berger, supra note 34, at 536.

That this understanding of substantial deference to the plaintiff's choice applies in California is strongly suggested by a court of appeal case cited by the Holmes court, International Harvester Co. v. Superior Court, 95 Cal. App. 3d 652, 157 Cal. Rptr. 324 (1979). International Harvester was a wrongful death action by survivors of a California resident killed in a truck accident in Kansas. The named defendant was Sears, Roebuck \& Co., the distributor of the truck tire blamed for the accident. Sears cross-complained against the truck manufacturer, International Harvester, seeking indemnity, and thereafter settled its cause of action with the plaimtiff. Id. at $654-55,157 \mathrm{Cal}$. Rptr. at 325. International Harvester moved for a forum non conveniens dismissal, contending that it would be more convenient to try the action in Kansas, where the aceident had occurred. Id. at 655, 157 Cal. Rptr. at 325.

In denying the petition, the court accorded the same deference to Sears, the original defendant, 
This interpretation suggests that the Gulf Oil language counsels caution in overriding the legitimate choice of a legislature as to when to exercise jurisdiction. It could be argued that forum non conveniens should be an extraordinary remedy not just because of distribution-ofpower concerns, but also precisely in order to accord substantial deference to even a nonresident plaintiff's choice. Since the Gulf Oil language cannot on its own support the Holmes court's interpretation, however, this argument requires policy justifications, which the Holmes court did not provide. And while there are several possible rationales for considering a resident plaintiff's subjective preference as a factor in the forum non conveniens calculus, ${ }^{116}$ the reasons for deferring to a nonresident's choice are at best obscure, ${ }^{117}$ and the Holmes decision does not clarify

as is normally enjoyed by the plaintiff in a forum non conveniens motion. Id. at $654,157 \mathrm{Cal}$. Rptr. at 325 (citing California's interest in encouraging settlement with injured plaintiffs and the long pendency of the action in California). It cited to Great Northern with a small but significant shift in language: "denial of a motion to dismiss or abate for absence of a convenient forum will not be overturned on appeal unless the "balance weighs strongly' in favor of the moving party." Id. at 656, 157 Cal. Rptr. at 326 (citing Great N. Ry. v. Superior Court, 12 Cal. App. 3d 105, 110, 90 Cal. Rptr. 461,465 (1970)) (emphasis added).

Sears, however, had not made the original choice to sue in California; it counterclaimed after having been haled into court by the original plaintiff in the case. The court nevertheless required a strong showing from International Harvester, the moving party. This preferred-position balancing in favor of Sears could not have served a policy of deference to plaintiff's choice, since the plaintiff who had chosen California was no longer in the case. Thus, prior to Holmes, at least some California courts interpreted the "substantial deference" language to refer to the allocation of burden of proof in the exercișe of an extraordinary remedy. Plaintiff's status was merely a proxy for this concern, not an independent factor of substantial weight.

116. Under a convemience to the parties approach, for example, the plaintiff's residency suggests that trial in the home fornm would not be unduly burdensome. Under a convenience to the courts approach, the plaintiff's residency can serve as a connection that justifies retaining jurisdiction. And under a substantive approach, it can trigger a substantive interest in compensating residents for their injuries. See supra text accompanying notes 32-34.

None of these policies, however, justifies according substantial deference to the choice of a nonresident plaintiff. All other things being equal, such status indicates that trial in the chosen forum is likely to be less convenient to the parties. See Piper Aircraft Co. v. Reyno, 454 U.S. 235, 255-56 (1981) ("When the home forum has been chosen, it is reasonable to assume that this choicc is convenient. When the plaintiff is foreign, however, this assumption is much less reasonable."). A plaintiff's nonresident status is also a poor proxy for converience to the courts. It increases the likelihood that the court will have to apply foreigu law, or at lcast will have to inake complicated choice of law decisions. See Gulf Oil v. Gilbert, 330 U.S. 501, 509 (1947). Finally, as inodern choice of law theory has demonstrated, nonresident plaintiff status without more does not inplicate substantive legislative interests of the forum. See generally Currie, Married Women's Contracts, supra note 26, especially at 237-41.

117. Although the Holmes court did not make them, arguments favoring deference to a nonresident plaintiff's choice can be offered, but they are relatively weak and bear little relation to the policies behind the forum non conveniens doctrine. For example, forums could decide that, as a policy matter, an injured party should have broad access to the courts. Such a policy also might be justified by the rationale that defendants are in general better able than plaintiffs to absorb the expense of litigating abroad. See Stein, supra note 8, at 817. But see 1 d. at 816 ("[A]t common law, just the opposite principle, that suit must be brought where the plaintiff finds the defendant, was enshrined in a Latin inaxim: actor sequitur forum rei."). Finally, forums inight conclude that there 
them.

\section{2. "Unsuitability" and Choice of Law}

Under traditional forum non conveniens doctrine, a court will not dismiss unless an alternative forum is available in which the action can be heard. ${ }^{118}$ The Holmes decision worked two important nutations on this principle. First, the court treated the availability of a suitable alternative forum as a discretionary factor within the forum non conveniens calculus, rather than as a thresliold inquiry. Second, the court incorporated into its appraisal of a suitable alternative forum the possibility of an unfavorable change in law, holding that England was an unsuitable foruin in large part because of its less-developed product liability law.

\section{a. The Assumption California Law Would Apply}

A fornm non convemens dismissal in Holmes would have resulted in an unfavorable change in law only if California law would have applied were the trial held in California. However, the court made no explicit resolution of the choice of law issue. In fact, so tenuous was the action's connection to the state that a Califorina court applying California choice of law rules might have been obliged to apply British law.

Hernandez v. Burger ${ }^{119}$ was a California conflict of laws case involving an automobile accident in Mexico between California resident defendants and a Mexican plaintiff. The court of appeal sustained the trial court's finding that under governmental interest analysis, Mexico's law of limited damages should apply. The court wrote:

$[N]$ o legitimate interest or policy of the State of California would be served by the application of its unlimited damages rule because the plaintiff is a resident and citizen of Mexico, the accident occurred in Mexico, and the only connection California lias with the case is that the defendants happen to be California residents and that California is the forum. ${ }^{120}$

The court refused to recognize a regulatory interest in the case, statimg that "California has no legitnnate interest in the possible deterrent effect of its unlimited recovery rule on conduct in Mexico. . . . Indeed, with respect to regulating or affecting conduct within its borders, tlie place of the wrong has the predominant interest." 121

is little need to protect the convenience interest of a nonresident plaintiff when the plaintiff is willing and eager to litigate in their courts, see Holmes, 156 Cal. App. 3d 372, 390, 202 Cal. Rptr. $773,784$.

118. Gulf Oil Corp. v. Gilbert, 330 U.S. 501, 506-07 (1947).

119. 102 Cal. App. 3d 795, 162 Cal. Rptr. 564 (1980).

120. Id. at $799,162 \mathrm{Cal}$. Rptr. at 566.

121. Id. at 800-02, $162 \mathrm{Cal}$. Rptr. at 567-68; see also Howe v. Diversified Builders, Inc., $262 \mathrm{Cal}$. App. 2d 741, 69 Cal. Rptr. 56 (1968). In Howe, a California court of appeal affirmed the application of Nevada law to a suit against California corporations by a Nevada resident for personal injuries 
This precedent may be distmguished im that the pleadings in Holmes were drafted to allege tortious conduct in California. ${ }^{122}$ Nevertheless, it is far from clear that California law would apply in Holmes, where, as in Hernandez, foreign nationals sued California residents for damages sustained in the alternative forum. ${ }^{123}$

\section{b. Unsuitability as a Discretionary Factor}

In most jurisdictions, the availability of an alternative forum is a prerequisite to the court's consideration of a motion to dismiss on forum non convemiens grounds. ${ }^{124}$ At a minimum, the moving party must be able to identify another forum where the cause of action is not barred by the statute of limitations and where the moving party is amenable to service. ${ }^{125}$ In addition, the Supreme Court has suggested that an alternative forum may be "unavailable" when the remedy it offers is "so clearly madequate or unsatisfactory that it is no remedy at all."126 If one of these circumstances exists, there is, in precise tern1s, no real forum non conveinens issue before the court; the other forum is inconvenient as a matter of law. ${ }^{127}$ In these situations, some courts refuse outright to dismiss pursuant to a forum non conveniens motion. ${ }^{128}$ More typically, the court will dismiss conditionally, subject to the alternative foruin's becommg available, as for example when the defendant agrees to submit to jurisdiction or to waive the statute of himitations in the alternative forum. ${ }^{129}$

The Holmes court, however, gave the concept of suitable alternative forum a very different focus, holding in effect that adequacy should be assessed not as a precondition for the discretionary forum non convemens mquiry, but rather as part of the discretionary calculus itself.

sustained in the course of performing work in Nevada. The court wrote, "[N]o California 'interest" would be promoted by impairing the ability of California corporations to compete for business in other states by imposing upon them obligations to the residents of such states which those states do not impose upon foreign corporations or their own domestic corporations." Id. at 746, 69 Cal. Rptr. at 59.

122. See supra notes $76-78$ and accompanying text.

123. See Hernandez, 102 Cal. App. 3d at 797, 162 Cal. Rptr. at 564.

124. See, eg., Ryan \& Berger, supra note 34, at 537-38 (availability of an alternative forum a prerequisite to consideration of a forum non conveniens motion); see also Piper Aircraft Co. $v$. Reyno, 454 U.S. 235, $254 \mathrm{n} .22$ (1981) ("At the outset of any forum non conveniens inquiry, the court must determine whether there exists an alternative forum.").

125. See Ryan \& Berger, supra note 34 , at 536-37.

126. Piper, 454 U.S. at 254.

127. See Comment, supra note 10, at 383 \& nn.63, 64 (unavailability of alternative forum); see, e.g., Tivoli Realty v. Interstate Circuit, 167 F.2d 155, 156-57 (5th Cir. 1948) ("At least two such fornms must be open before the doctrine comes in to play; and they shall not be dependent merely upon the will or grace of the defendant, but must be provided by law."), cert. denied, 334 U.S. 837 (1948).

128. See Comment, supra note 10 , at 383 n.63 (citing cases).

129. Ryan \& Berger, supra note 34 , at 539. 
The court held that as part of that discretionary evaluation, the trial court should consider the possiblility of an unfavorable change in law. ${ }^{130}$ In support of its inore contextual definition of suitable alternative forum, the court seized upon language froin the commentary in the California codification of the forun non conveniens doctrine which states that "the action will not be dismissed unless a suitable alternative forum is available to the plaintiff." 131 The Holmes court seems to have construed this language to mean that California law requires not only that there be an alternative forum where it is possible to commence an action and obtain a valid judgment against the defendant, but also that the alternative forum have a "suitable" substantive law.

This interpretation of the legislative commentary is not persuasive. First, the commentary itself states that the requirement of a suitable alternative forum is intended to preclude granting a forum non conveniens inotion when the defendant is not subject to jurisdiction in the alternative forum or the suit would be barred there by the statute of limitations. ${ }^{132}$ Second, the cited commentary rehes upon a case that clearly construes "suitable alternative forum" in its ortlodox sense of a forum in which the action can be brought. ${ }^{133}$ The court in that case held that "forum non conveniens ... presupposes at least two forums in which the defendant is amenable to process." 134 California law before Holmes thus had incorporated the same limited nondiscretionary concept of a suitable alternative forum as its federal counterpart.

It was a fairly significant departure from precedent for the Holmes court to treat suitable alternative forum as a relative notion located within the foruin non convemiens calculus, rather than as a prerequisite to the invocation of the doctrine. Whether the Holmes court's departure was intentional or madvertent, it enabled the court to consider "possible differences in conflict of law rules and any substantial disadvantage from a change im forum"135 under a heading whose importance and legitimacy were well-established in case law.

130. Holmes v. Syntex Laboratories, Inc., 156 Cal. App. 3d 372, 381-82, 202 Cal. Rptr. 773, 778-79 (1984).

131. Id. at 379, 202 Cal. Rptr. at 777 (quoting CAL. Clv. Proc. CoDE $\$ 410.30$ Judicial Council comment 490, 492 (West 1973)) (emphasis added by the Holmes court).

132. Cal. Civ. Proc. Code $\S 410.30$ Judicial Council comment, at 492.

133. See Hill v. Upper Miss. Towing Corp., 252 Minn. 165, 89 N.W.2d 654 (1958).

134. Id. at 172, 89 N.W.2d at 660 (quoting Gulf Oil Corp. v. Gilbert, 330 U.S. 501, 506 (1947)). The Hill court's conception of suitable alternative forum was, if anything, more mechanical. The court held that Tennessee was not a suitable alternative forum since the defendant was not subject to involuntary process in Tennessee, even though the defendant had offered to submit to jurisdiction there. $I d$.

135. 156 Cal. App. 3d at 383, 202 Cal. Rptr. at 780. 


\section{c. Construing Unsuitability to Include the Possibility of an Unfavorable Change in Law}

Having defined suitability as a discretionary factor within the foruin non conveniens calculus, the Holmes court went on to incorporate in its notion of unsuitability the possibility of an unfavorable change of law. The result was at odds with prior federal and California cases holding that a showing that recovery would be nore difficult or even inpossible in a foreign foruin does not deinonstrate that the alternative foruin is inadequate. ${ }^{136}$ Again, the decision's unorthodoxy was inade to appear conventional. The court relied on a factor that in previous foruin non conveniens cases had referred to an entirely different idea.

Coinparing California and federal law, the court concluded that "California attaclies far greater significance to the possibility of an unfavorable change in applicable law resulting froin a forum non conveniens dismissal."137 The court relied upon case law holding that ainong the factors relevant to a forum non conveniens inquiry is " " $\mathrm{t}]$ he difference in conflict of law rules applicable $m$ this state and in [the] alternative forum." "138 The court concluded that a difference in the applicable law could work to deprive the plaintiff of a suitable alternative foruin. ${ }^{139}$

The consideration of conflict of law rules is in fact firmly embedded in both federal and California forum non conveniens law, and has been recognized at least since Gulf Oil Corp. v. Gilbert. ${ }^{140}$ Not before Holmes, lowever, was this factor given such a substantive rather than procedural twist. The reason given in prior case law for considernig different conflict of law rules is to avoid practical difficulties of applying the conflict rules of anotlier state. ${ }^{141}$ Conventional forum non conveniens doctrine thus recognizes the convenience of trying the action in a forum that is familiar with the law to be applied. The cominentary to Section 410.30 of the California Code of Civil Procedure incorporates this idea by quot-

136. See Dowling v. Richardson-Merrell, Inc., 727 F.2d 608 (6th Cir. 1984) (federal law); see also Great N. Ry. Co. v. Superior Court, 12 Cal. App. 3d 105, 112, 90 Cal. Rptr. 461, 466 (1970) (California law), cert. denied, 401 U.S. 1013 (1971).

137. Holmes, $156 \mathrm{Cal}$. App. 3d at 381, 202 Cal. Rptr. at 778.

138. Id. (citing Great Northern, 12 Cal. App. 3d at 113, 90 Cal. Rptr. at 466).

139. $156 \mathrm{Cal}$. App. 3d at 381-82, $202 \mathrm{Cal}$. Rptr. at 778-79.

140. 330 U.S. 501,509 (1947). Onc reason this factor came to play a central role in forum non conveniens law is that the early cases recognizing application of the doctrine often involved knotty problems of conflict of law rules. For example, admiralty cases, interference-with-state-government cases, and internal-affairs-of-foreign-corporation cases share the common trait that the court often must determine difficult questions under laws of another jurisdiction. Comment, supra note 11, at 923-24; see also Blair, supra note 11, at 21-23.

141. Gulf Oil, 330 U.S. at 509. Conflict of laws issues implieate convenience to the court in deciding the case. They are among "those factors which go to make the trial of a case easy, expeditious, and inexpensive." Ryan \& Berger, supra note 34 , at 550, and cases cited therein. See supra text accompanying note 21 . 
ing a passage froin Gulf Oil. "There is an appropriateness, too, in having the trial ... in a forum that is at hoine with the ... law that must govern the case, rather than having a court in soine other forum untangle problems in conflict of laws, and in law foreign to itself." 142

The language of Section 410.30, moreover, does not support the Holmes court's imterpretation of the conflict of laws factor. The statute directs a court to stay or dismiss an action when it finds that in the interests of substantial justice the action should be heard in a forum outside the state. ${ }^{143}$ The miphication is that jurisdiction should normally be retained unless "substantial justice" deınands otherwise. Therefore, if by "substantial justice" the statute referred to a coinparison between substantive laws, it would be directing Califorma courts to dismiss an action ouly when it appears that the laws of the alternative foruin are more favorable or fair than the forum's own. This would entail the unusual decision that the forum's own law is so less fair than that of the alternative foruin as to cause a failure of justice if jurisdiction were retained. ${ }^{144}$ Rather, the failure-of-justice language must refer to practical problems that would arise if the suit were heard in the home forum, ${ }^{145}$ as for exain-

142. Cal. Civ. Proc. Code $\$ 410.30$ Judicial Council comment, at 493 (West 1973) (citing Gulf Oil Corp. v. Gilbert, 330 U.S. 501, 509 (1947)); see also Harrison v. Wyeth Laboratories, 510 F. Supp. 1 (E.D. Pa. 1980) (granting conditional forum non conveniens dismissal so that international product liability litigation could be heard in England), aff'd mem., 676 F.2d 685 (3d Cir. 1982). The Wyeth court wrote: "A Court versed in the law that must govern the case and familiar with the people and the commurity in which the law is to govern, is better able to establish the appropriate legal standards and apply them ...." Id. at 4.

Even sophisticated courts well versed in conflict of laws theory may be anxious and uncertain about applying the laws of a foreign country.

'[T]ry as we inay to apply foreign law as it comes to us through the hips of experts, there is an inevitable hazard that ... our labors, moulded by our own habits of inind as they necessarily inust be, may produce a result whose conformity with that of a foreign court may be greater in theory than it is in fact.'

Hernandez v. Cali, Inc., 32 A.D. 2d 192, 195, 301 N.Y.S.2d 397, 401 (1969) (quoting Conte v. Flota Mercante Del Estado, 277 F.2d 664, 667 (2d Cir. 1960) (Friendly, J.)); see also Dowling v. Richardson-Merrell, Inc., 727 F.2d 608 (6th Cir. 1984).

143. Cal. Civ. Proc. Code $\$$ 410.30(a) (West 1973).

144. Moreover, the experience of courts that employ a better-law approach to conflict of laws indicates that few if any courts would be willing to declare foreign law more fair. See R. CRAMTON, D. CURrie \& H. KAY, CONFLICT OF LAwS, CASES-COMMENTS-Questions 338 (3d ed. 1981).

145. See, e.g., CAL. Civ. Proc. CODE $\$ 410.30$ (a) (West 1973) ("When a court upon inotion of a party or its own motion finds that in the interest of substantial justice an action should be heard in a forum outside this state, the court shall stay or dismiss the action in whole or in part on any conditions that may be just." (emphasis added)); see also Barrett, supra note 11, at 393 (suggesting that under "the broad doctrine of forum non conveniens . . . any plaintiff . . . may be denied the right to bring his suit when the ends of justice would be better served by trial in another court" (einphasis added)); $c f$. Williams v. Green Bay \& W. R.R., 326 U.S. 549, 55455 (1946) ("[The forum non conveniens doctrine] was designed as an 'instrument of justice.' Maintenance of a suit away from the domicile of the defendant ... might be vexatious or oppressive. An adventitious circumstance might land a case in one court when in fairness it should be tried in another." (emphasis added) (footnotes omitted)); A. GibB, THE INTERNATIONAL LAW OF JURISDICTION IN ENGLAND AND SCOTLAND 212 (1926) ("[T]he court will not hold its hand unless there be, in the circumstances of the case, such 
ple, when crucial witnesses were unavailable, or production of witnesses and records would seriously disrupt a business, ${ }^{146}$ or the court would be burdened with complex conflict of law inquiries. ${ }^{147}$

In its imterpretation of prior doctrine and its application of precedent, then, the Holmes decision is flawed. It too willingly assumes that California had a sufficient interest to justify application of its law to the action. It exploits language defining forum non conveniens as an extraordinary remedy to promote a rule of substantial deference to nonresident plaintiffs that has no apparent basis in policy. Finally, by recharacterizing suitability of an alternative forum as a discretionary factor that takes into account the possibility of an unfavorable change in law, the opinion misimterprets the estabhished factor of differences in conflict of law rules. The result of these departures from doctrine is that the Holmes decision has made new law. And while the court may be criticized for inaking new law under cover of precedent, the more inportant question remains: Did it make good new law?

\section{III}

Should THE Forum Non Conveniens Doctrine

TAKe ACCOUNT OF AN UNFAVORABLE CHANGE IN LAW?

This Part explores the forum non convemiens doctrine and the policies that underlie it in order to assess the core holding of the Holmes decision. It suggests that the Holmes decision applies a substantive model of forum non conveniens doctrine. It then argues that such an approach has merit, but that even under a substantive model, the decision of the Holmes court to factor into the forum non conveniens doctrine the possibility of an unfavorable choice of law was wrong.

\section{A. A Substantive Approach to Forum Non Conveniens}

The Holmes court's decision to overturn the forum non conveniens disinissal as an abuse of discretion rested on two dubious findings: that California gives substantial deference to a nonresident plaintiff's choice of forum and that California had "an interest in regulating the foreign

\footnotetext{
hardship on the party setting up the plea as would amount to vexatiousness or oppression if the court persisted in exercising jurisdiction." (emphasis added)).

146. See Barrett, supra note 11, at 381-82.

147. Moreover, a recent California court of appeal decision explicitly declined to follow the Holmes court's interpretation. Corrigan v. Bjork Shiley Corp., 182 Cal. App. 3d 166, 178, 227 Cal. Rptr. 247, 253 (1986) ("Under California law, the purpose of comparing the differences in conflict of law rules and the differences in substantive law which will be applied, once the choice of law has been made in each alternative forum, is not simply to decide which foruin would provide the most advantageous law froin the viewpoint of the plaintiff. To the extent Holmes explicitly or inplicitly directs otherwise, we decline to follow it.").
} 
marketing of defective products alleged to have been developed in California." 148 But however faulty the court's analysis of California's interest may have been, it is noteworthy that a state regulatory interest figured so prominently in a forum non conveniens analysis at all. The decision seems to marry forum non convemiens and California's goverumental interest analysis approach to conflict of laws, which, unlike conventional forum non conveniens doctrine, is designed to consider substantive legislative interests. ${ }^{149}$ Thus viewed, the case appears to announce a substantively driven forum non conveniens doctrine in California. ${ }^{150}$

Under a substantive approach to forum non conveniens, courts would be expected to factor in whether or not the forum has an interest in the application of its substantive policies, and whether or not such an interest would be defeated by declining to exercise jurisdiction. If a nonresident plaintiff's choice of forum were a legitimate state concern, granting a forum non conveniens notion that would force the plaintiff to bring her claim under a less hospitable law would injure the state imterest in protectimg the plaintiff's original choice. And if California had a legitimate regnlatory interest in Holmes, the interest might have been defeated by the application of British law by a British court. Perhaps cases like Holmes and Brown v. Clorox Co. ${ }^{151}$ mark a healthy evolution in forum non convemiens doctrine. Modern choice of law theory has come to address the question, "Does the forum have a sufficient interest to justify the application of its own law?" To a more limited extent, jurisdiction analysis now also considers the forum's interest. ${ }^{152}$ Perhaps forum non conveniens as well should candidly incorporate a substantive coinponent.

\section{The Case for a Substantive Approach}

Nearly all jurisdictions consider both convenience to the parties and convemience to the courts im their forum non convemiens analyses, ${ }^{153}$ but few if any reserve an explicit role for the forum's substantive interests: ${ }^{154}$ On its surface, this limitation accords with the intuitive sense that a procedural litigation-allocation device such as forum non conveniens should

148. Holmes, 156 Cal. App. $3 \mathrm{~d}$ at 389, 202 Cal. Rptr. at 784; see also id. at 391, 202 Cal. Rptr. at 785 .

149. See Reich v. Purcell, 67 Cal. 2d 551, 432 P.2d 727, 63 Cal. Rptr. 31 (1967).

150. See Corrigan v. Bjork Shiley Corp., 182 Cal. App. 3d 166, 183, 227 Cal. Rptr. 247, 257 (1986) (referring explicitly to the "Holmes substantive law analysis approach").

151. 56 Cal. App. 3d 306, 128 Cal. Rptr. 385 (1976). See text accompanying notes 72-74.

152. See, e.g., World-wide Volkswagen Corp. v. Woodson, 444 U.S. 286, 292 (1980); McGee v. International Life Ins. Co., 355 U.S. 220, 223 (1957).

153. Barrett, supra note 11, at 408 (citing Gulf Oil Corp. v. Gilbert, 330 U.S. 501, 508 (1947)). As noted, however, the way in which a factor such as plaintiff's residency is considered will be affected by the policy decision as to why it matters. See supra text accompanying notes 32-34.

154. See Note, Foreign Plaintiffs and Forum Non Conveniens: Going Beyond Reyno, 64 TEx. L. REV. 193, 217 (1985). 
not be tainted by the concern for outcome that a substantive approach implies. ${ }^{155}$ However, taking account of substantive concerns in the forum non convemens doctrine may be desirable in theory and unavoidable in practice.

In practice, the cases that stress the policy of convemience to the courts mevitably contain judgments about the legitimate scope of the forum's interest in the apphication of its law. ${ }^{156}$ The concern for conserving judicial resources is present in any trial; the decision of when and how to expend thein will depend on the foruin's connection to the controversy. ${ }^{157}$ For example, while "[j]ury duty is a burden that ought not to be imposed upon the people of a commumity which has no relation to the litigation,"158 it presumably is appropriate to impose it where the state has an interest in the apphication of its substantive policy. Suits that implicate the state's imterest are not necessarily inore convenient to try, yet there is nevertheless "a local interest in having locahized controversies decided at home."159

California's pohicy of not granting a forum non conveniens dismissal agaimst a resident plaintiff provides another example. Adjudication is not always more convenient to the court when the plaintiff is a resident. In the words of the California Supreme Court, "[t]his limitation of the forum non conveniens doctrine does not rest on any conclusion derived from a balancing of convemiences; it reflects an overriding state policy of assuring California residents an adequate forum for the redress of grievances."160

It might be argued that to identify a substantive element inhering in the convemence-to-courts policy confuses the court's concern for its appropriate admimistrative function as a forum open to residents ${ }^{161}$ with the substantive interests of the state. The policy of ensuring residents access to local forums, for example, could be framed in terins that make

155. Cf. P. Freund, ON LAW AND JUSTICE 100 (1968) ("Much of law is designed to avoid the necessity for the judge to reach Holmes' 'can't helps,' his ultimate convictions or values.").

156. See Stein, supra note 11, at 821-22 (discussing the extent to which "the evaluation of public factors under Gulf Oil does constitute a substantive judgment about the extent of the respective forums' stakes in the controversy .... ."); see also id. at 840.

157. See Brown v. Clorox Co., 56 Cal. App. 3d 306, 313, 128 Cal. Rptr. 385, 391 (1976):

Every lawsuit tried places a burden upon the courts, but at least one of the functions of courts is to try lawsuits. ... In the case before us, the relationship of the respondents to this state, and the activities of those respondents ... . does not lead to a conclusion that prosecution of this action in this state would 'place a burden on the courts of this state which is unfair, inequitable or disproportionate.'

Id. (quoting CAL. Code Crv. Proc $\$ 410.30$ Judicial Council comment (West 1973)).

158. Gulf Oil Corp. v. Gilbert, 330 U.S. 501, 508-09 (1947).

159. Id. at 509.

160. Archibald v. Cinerama Hotels, 15 Cal. 3d 853, 859, 544 P.2d 947, 951, 126 Cal. Rptr. 811, 815 (1976).

161. See supra notes $34,64, \& 157$. 
it appear fundamentally different from a forum's substantive interest in who wins the case and why. A primary administrative function of the court is to provide a forum for residents to bring their grievances. But framing the policy in this way does not invalidate a substantive model, because courts' constitutive purposes can be variously expressed. As well as being meant to provide a forum for residents, courts also are set up to apply legislative policies to cases that implicate the forum's interest in those policies. ${ }^{162}$ Labelling one function "substantive" and the other "administrative" only obscures the fact that in either case, judgments about which burdens a court should shoulder depend on the forum's interest in the controversy.

If convenience-to-courts interests properly entail consideration of substantive concerns, then rejecting any accounting for substantive concerns requires limiting the forum non convemiens calculus to factors of convenience to the parties. This approach would represent a radical parsing of the doctrine as it has been applied in all jurisdictions; even the Piper decision recognizes the continuing vitality of the Gulf Oil publicinterest factors. ${ }^{163}$ More importantly, a model based exclusively on the parties' convenience would ignore the choice of law issues that underlie most forum non conveniens disputes. ${ }^{164}$ It seenis disingenuous and illadvised to resolve the real point at issue only mcidentally under the banner of maximizing convenience to the parties. Since the parties so frequently are fighting over whether the forum should retain jurisdiction and apply its own law, ${ }^{165}$ it makes better sense for the court to apply an analysis tailored to that issue, evaluating, along with the balance of conveniences, the question whether the forum has an interest in the applica-

162. Cf. United States Merchants' \& Shippers' Ins. Co. v. A/S Den Norske Afrika Og Australie Line, 65 F.2d 392, 394 (2d Cir. 1933) (Learned Hand, J.) ("Though it is quite true that courts are primarily naintained for the benefit of citizens, access to then is only to secure justice.").

163. See Piper Aircraft Co. v. Reyno, 454 U.S. 235, 241 \& n.6 (1981).

164. See note 10 and accompanying text.

The plaintiff in Piper admitted candidly that she filed suit in the United States "because its laws regarding liability, capacity to sue, and damages are more favorable to her position than are those of Scotland." Piper, 454 U.S. at 240.

165. The Supreme Court's decision in Van Dusen v. Barrack, 376 U.S. 612 (1964), may implicitly recognize the choice of law implications that inhere in forum non conveniens decisions, and therefore may lend additional support to a substantive nodel. The Court held in Van Dusen that a transfer in the federal system under Section 1404(a) "sliould be, witl respect to [applicable] law, but a change of courtrooms." Id. at 639 (footnote omitted). However, the Court explicitly reserved the question whether the law of the transferor forum would apply where the state court in the forum state would have granted a forum non conveniens motion. Id. at 640 . The inplication is that forum non conveniens dismissals normally entail a change in applicable choice of law rules. In a transferred case in which the state court would dismiss on forum non conveniens grounds, it therefore night be necessary to apply the law of the transferee forum in order to preserve parallelism between the federal and state systems. Cf. Currie, Change of Venue and the Confict of Laws: $A$ Retraction, 27 U. CHI. L. REV. 341, 348-51 (1960). This recognition in turn acknowledges the substantive consequences of forum non conveniens decisions. 
tion of its substantive policies. ${ }^{166}$

The recent forum non conveniens dismissal in tlie Bliopal disaster litigation seems to liave adopted sucl an approacl. In its consideration of the balance of public-interest factors, the court added a new entry to the Gulf Oil list: "The Interests of India and the United States."167 The plaintiffs liad argued that a dismissal would promote a double standard of liability for multimational corporations, and urged that "Anierican courts sliould administer justice to the victims of the Bliopal disaster as they would to potential American victims of industrial accidents."168 In rejecting this argument and granting the conditional dismissal, ${ }^{169}$ the court analyzed at lengtli the interests of the two sovereigns in the litigation, whicli revealed "tlie immense interest of various Indian goverumental agencies in the creation, operation, licensing and regulation, and investigation of the plant." 170 The court concluded, "No Ainerican interest in the outcome of this litigation outweiglis the interest of India in applying Indian law and Indian values to the task of resolving this case." 171

The otler side of the spectrun from a forum non conveniens doctrine purged of all substantive concerns is a purely substantive model, under which dismissal would be barred as a matter of law when the forum lias an interest. This approacli is also faulty. It would emasculate the doctrine and leave it merely replicative of clioice of law analysis. Under a pure substantive niodel, a court would lack the discretion to dismiss when the forum liad an interest in the litigation, even if other factors pointed strongly towards dismissal; likewise, it would not be able

166. An alternative suggestion is that the court integrate into its forum non conveniens analysis its particular jurisdiction's choice of law doctrine. The court would then be factoring in whether local law would be likely to apply if jurisdiction were retained, which in most jurisdictions is a very different inquiry from whether the forum has an interest in the application of its substantive policies. Only two jurisdictions currently employ interest analysis, and the majority use either the traditional vested-rights theory of the original Restatement or the Restatement Second "Most Significant Relationship" approach. Kay, Theory into Practice: Choice of Law in the Courts, 54 Mercer L. REv. 521, 591-92 (1983). The 14 states that have adopted the Restatement Second approach, see id., do address the forum's interest, but only in a roundabout way, see RESTATEMENT (SECOND) of CONFLICT OF LAwS $\S 6(2)(1971)$, id. comment e, that is likely to further complicate forum non conveniens analysis, see infra note 175 . Interest analysis is proposed here as a ready tool-one that happens to be imported from a particular choice of law doctrine-to aid in determinations of when it is fair or just to decline jurisdiction and thereby effect a change of law. The arguinents for a substantive approach, however, do not extend to a mechanistic replication at the forum non conveniens stage of a jurisdiction's individual choice of law doctrine.

167. In $R e$ Union Carbide Corp. Gas Plant Disaster, 634 F. Supp. 842, 862 (S.D.N.Y. 1986).

168. Id.

169. The court dismissed the case subject to a number of conditions, most notably that Union Carbide submit to discovery governed by rules and procedures contained in the Federal Rules of Civil Procedure. Id. at 867.

170. Id. at 863-64.

171. Id. at 867 . 
to retain jurisdiction when it would be necessary to apply the law of the alternative forum. In the words of the Supreme Court, "if conclusive or substantial weight were given to the possibility of a change in law, the forum non conveniens doctrine would becoine virtually useless." 172

The appropriate role for substantive concerns in the foruin non conveniens doctrine, then, is as another factor to be weighed in the balance. A court might properly pose an additional question in the foruin non convemens hitany: "Does the forum have an interest in applying its law to the litigation?" Thus, the Holmes decision might point the way, however cluinsily, to a welcome adjustinent in the doctrine.

A court applying a substantive approach would not necessarily have to limit itself to gauging the foruun's mterest in the application of its law. One way of viewing the foruin non conveniens doctrine is as a fine-tuning discretionary device to screen out those cases that should not be tried in

172. Piper, 454 U.S. at 250; see Corrigan v. Bjork Shiley Corp., 182 Cal. App. 3d 166, 182, 227 Cal. Rptr. 247, 256-57 (1986) (commenting on the Holmes court's analysis of "suitability" and choice of law, see supra text accompanying notes 118-47, and holding that "the case cannot turn on this disadvantage in different substantive law.").

Giving conclusive weight to a forum's interest in the hitigation also would substantially reduce the number of forum non conveniens disınissals, and this result would aggravate some practical probleins the doctrine is designed to alleviate. It would harm the convenience-to-courts interests that have been a vital part of the forum non conveniens doctrine in several ways. First would be an increase in the business of already congested courts, especially in states with recovery rules favorable to plaintiffs. Cf. Atchison, T. \& S.F. Ry. v. District Court, 298 P.2d 427 (Okla. 1956) (Oklahoma Suprene Court grants fornm non conveniens motion where litigation has hittle connection to the state, because to do otherwise "would in effect be opening wide the doors of the courts of this state and extending an invitation to prospective litigants everywhere to bring their hitigation here without fear of disınissal, and the doctrine of forum non convelniens would thereby be rendered counpletely ineffective."), cert. denied., 352 U.S. 879 (1956). The impact would be especially pronounced in international product liability litigation, which typically involves a large investınent of judicial resources.

Another practical problem with a pure substantive model is that it could force defendants to sue for indemnification in the alternative forum. When the alternative fornin is the situs of the injury and much of the evidence, often some tortfeasors are not subject to jurisdiction in the chosen forum. The parties inay have to endure the burden of trial on the merits $m$ the chosen forum followed by a suit for indemnification in the alternative forum. A related difficulty is the possibility of inconsistent verdicts. See Hemmelgarn v. Boeing Co., 106 Cal. App. 3d 576, 588-89, 165 Cal. Rptr. 190, 196-97 (1980) (Court of Appeal affinns a fornm non conveniens dismissal because California's interest in just apportionment in inultiparty tort hitigation would be better served by trial in Canada).

The Holmes approach, Inoreover, would lead courts into especially burdensome and intricate choice of law inquiries. See Piper, 454 U.S. at 251. The Holmes approach requires courts to compare actual patterns of application of law between the two forums. They thus would have to receive and consider evidence of actual outcoines in the alternative forum, second-guessing the efficacy with which the alternative forum's legislative policies have been applied. This also raises a related concern that a foruin non conveniens dispute could lead to a protracted adjudication that could significantly forestall recovery. For example, the trial on the merits in Piper was delayed two and a half years while the forum non conveniens motion was litigated to the Supreme Court. Under the Holmes mutation, a foruin non conveniens motion could assume the scope of a full trial, with courts having to consider and rule on the intricacies of the alternative forum law in its actual application. 
the home forum, notwithstanding that jurisdiction is properly founded there. As such, it allows for consideration of factors that currently have no bearing on other hitigation-allocation mquiries, such as the plaintiff's contacts to the foruin, which currently play but a very slight role in jurisdiction analysis. ${ }^{173}$

Similarly, whereas interest analysis rejects weighing the interests of competing forums, foruin non convemens might allow for balancing the intensity of the forun's interest against the intensity of the alternative forum's interest. An example is provided by the opinion in the Bhopal disaster litigation, in which the court concluded that " $[t]$ he Indian interest in creating standards of care, enforcing thein or even extending them, and of protecting its citizens froin ill-use is significantly stronger than the local interest in deterring inultinationals froin exporting allegedly dangerous technology."174 Thus, factoring in substantive concerns could cut both ways. It might weigh in favor of dismissal that the alternative foruin has a substantially greater interest in the litigation, even though the home forum's interest is adequate to apply its own law. ${ }^{175}$

\section{Unfavorable Change in Law Under the Substantive Model}

A substantively driven forum non conveniens doctrine would not support the Holmes decision, because under governmental interest analysis California probably lacked an interest sufficient to justify application of its law. ${ }^{176}$ In fact, California's interest in the Holmes litigation was

173. See Keeton v. Hustler, 465 U.S. 770, 779-80 (1984).

174. In Re Union Carbide Corp. Gas Plant Disaster, 634 F. Supp. 842, 865 (S.D.N.Y. 1986). See Currie, The Constitution and the "Transitory" Cause of Action (pt. 1), 73 HARv. L. REv. 36, 81 (1959).

175. Cf. Currie, Married Women's Contracts, supra note 26, at 240 (civilized states might properly decline to apply their law when their own interest is slight and the alternative forun's is substantial and legitimate). Allowing for comparisons of the intensity of conpeting forums' interests, as opposed to simply asking whether the chosen forum has an interest, does accord with forun non conveniens's role as a discretionary doctrine. Furthermore, deferring to another forun with a substantially greater niterest might be an attribute appropriate to an evolved systen of justice, $c f$. M/S Brenien v. Zapata Off-Shore Co., 407 U.S. 1 (1972) (upholding choice-of-court clause specifying litigation in England, because it would be parochial not to recognize the competency of nany foreign forun1s); Hilton v. Guyot, 159 U.S. 113, 202-03 (1895) (comity interest in the recognition of foreign judgments), and also miglit advance the forun's substantive policies in the long run by encouraging other forums to reciprocate, cf. Currie \& Schreter (now Kay), Unconstitutional Discrimination in the Conflict of Laws: Privileges and Immunities, 69 YALE L.J. 1323, 1361 (1960).

On the other hand, such a "most significant relationship" approacl, cf. RESTATEMENT (SECOND) OF CONFLICT OF LAWS $\S 145$ (1971), could entangle courts in nore complicated comparisons, contrary to the convenience-to-courts policy of forunı non conveniens. See note 142 and accompanying text; Piper Aircraft Co. v. Reyno, 454 U.S. 235, 251 (1981) ("The doctrine of forum non conveniens . . . is designed in part to help courts avoid conducting complex exercises in coniparative law.").

176. See supra notes 119-23 and accompanying text.

Others of the "Pill Cares" kindred to Holmes, see note 76 and accompanying text, rejected 
less than Pennsylvania's interest in Piper. The tortious conduct alleged in Piper posed a danger to the residents of Pennsylvania, as well as to those of Scotland. ${ }^{177}$ To the extent the defendants in Piper were inarketing defective airplane engines or propellers, Pennsylvania residents bore part of the risk of those defective products. In contrast, the gravanien of the coinplaint in Holmes was a failure to warn foreign citizens. ${ }^{178}$ An American corporation's duty to warn with respect to products inarketed in the United States is governed by doinestic regulatory scheines entirely distinct froin the British systen.

plaintiff's' argument that a governmental interest existed that was sufficiently compelling to justify denial of a forum non conveniens motion. The Holmes court, im fact, provides the sole discordant voice in a chorus of contrary holdings. See, e.g., Dowling v. Richardson-Merrell, Inc., 727 F.2d 608 (6th Cir. 1984); Harrison v. Wyeth Laboratories, 510 F. Supp. 1 (E.D. Pa. 1980), aff'd mem., 676 F.2d 685 (3d Cir. 1982); Jones v. Searle Laboratories, 93 Ill. 2d 366, 444 N.E.2d 157 (1982); Bewers v. American Home Products Corp., 99 A.D. 2d 949, 472 N.Y.S.2d 637 (1984), aff'd, 64 N.Y.2d 630, 474 N.E.2d 247, 485 N.Y.S.2d 39 (1984).

The cause of action in Harrison, for example, is nearly imdistinguishable from Holmes. The plaintiffs in Harrison alleged that defendant, an American corporation with its principal place of business in Pennsylvania, caused the marketing, sale, and distribution of the contraceptives in the United Kingdom through its imdependent subsidiary there. The complaimt, like the one in Holmes, was framed to focus on alleged tortious conduct in Pennsylvama cousisting of "marketing the drugs and placing them in the stream of commerce with knowledge that the warning accompanying the drugs was inadequate, thus creating an unreasonable risk of harm, irrespective of where the drugs were sold." Harrison, 510 F. Supp. at 3 (emphasis in original). Adopting a line of argument that would first gain judicial approval in Holmes, the plaintiffs further argued that Pennsylvama had "an interest in and direct conceru with the safety of products which emanate from its borders, and with conduct which occurs within Pennsylvania which may cause harm to others, regardless of where that harm may have occurred." Id.

The district court was not persuaded. It held that even assuming production and narketing decisions had been made by the defendant in Pennsylvania, there was no regulatory interest weighing in favor of retaining jurisdiction. The court wrote:

[T] he courts of the United States are ill-equipped to set a standard of product safety for drugs sold in other countries... The United States should not impose its own view of the safety, warning, and duty of care required of drugs sold in the United States upon a foreign country when those same drugs are sold in that country.

Id. at 4 (emphasis in original).

177. See Note, supra note 9, at 1280 . It could be argued that even though the alleged conduct posed no threat to Califonna plaintiffs, California nevertheless had an interest in the case. The argument would be that American product hability law has developed not only to protect American plaintiffs, but also to deter and regulate American companies, regardless of whom their conduct threatens, and to ensure that no victims of American industrial development go uncompensated. See Note, supra note 9, at 1273-74; Speiser, $A$ Solution to the Bhopal Dilemma, Nat'1 L.J., Feb. 3, 1986, at 13, col. 1 ("Yet, if Judge Keenan granted Union Carbide's request to decline jurisdiction, he would relegate the Indian claimants to unconscionably meager compensation and would stifle the deterrent power of American law, which is capable of forcing our multinational corporations to take more care for human life."); Greenberg, supra note 8, at 182-83 (federal foreign policy interest).

Currie and Kay coined the term "altruistic interest" to describe and evaluate a forum's application of its own law to benefit nonresidents even when such application would not advance the specific legislative policy embodied in the law. E.g., Currie \& Schreter, supra note 175, at 1361. They concluded that such an "interest" might be sufficient to withstand a due process attack against the application of the forum's law. Id.

178. 156 Cal. App. 3d 372, 376, 202 Cal. Rptr. 773, 775 (1984). 
However, a substantive model seems particularly apt in international product liability cases such as Holmes. The core concerns facing the courts in these cases are less issues of convenience ${ }^{179}$ than issues of when it is fair or just to impose American standards of liability on foreign transactions, or, viewed from the opposite perspective, when it is fair to allow "American defendants reaping profits from overseas operations [to] be subject to less stringent liability standards."180 The contribution of a substantive model to that problem would be to lielp screen out those cases in which the forum liad no interest in the application of its substantive policies, a technique like tliat brouglit by choice of law interest analysis to similarly difficult questions of policy. In Holmes, for example, it is the real possibility that California had no interest in the case that makes the court's eagerness "to export Califorina law"181 so problematic. If California lrad no substantive interest, the Holmes court's conclusion that Califorina law would provide a more enlightened resolution to the case $^{182}$ seems academic.

Moreover, the assumption that California's product liability law would have achieved a more just result in the case is troubling and may be unwarranted. ${ }^{183}$ Alternative forums like Great Britain have worked out their own policy resolutions of risk-allocation problems, which could be defeated by exposure to American standards of liability merely because jurisdiction lies over an American parent of a foreign company. ${ }^{184}$ The subsidiary companies presumably will internalize the cost of higher liability by passing the increased cost of doing business along to

179. International product liability cases, in fact, often present the ironic situation of parties asking the court to make litigation more inconvenient for them. Typically, the American defendants are arguing trial would be more convenient abroad, while the foreign plaintiffs are only too happy to shoulder the "burden" of litigating in the United States. See Note, supra note 154, at 215-16.

180. Id. at 220 .

181. See Stein, supra note 8 , at 840 .

182. Holmes, $156 \mathrm{Cal}$. App. 3d at 383-86, 202 Cal. Rptr. at 780-82.

183. The wisdom of a kind of "better law" approach to forum non conveniens is all the more questionable in light of the finding that those jurisdictions that adopt Professor Leflar's better-law approach to choice of law almost inevitably apply the forum's own law. See R. CRAMTON, D. CURRIE \& H. KAY, supra note 144, at 338; Leflar, Choice-Influencing Considerations in Conflicts Law, 41 N.Y.U. L. REV. 267, 298-99 (1966). The better law becomes tantamount to local law. Thus, in application, the apparently paternalistic better-law approach may be merely parochial.

184. See Besharov \& Reuter, Tort Laws Hobble U.S. Business Abroad, Wall St. J., Oct. 28, 1985, at 22 , col. 3.

Other countries do not want, and cannot afford, U.S. levels of liability. It is another expression of the well-known American ideological imperialism to expect other nations to want not only U.S. technology but also all the legal protections that Americans have put in place for themselves, including strict liability in manufacturing, liberal recovery for pain and suffering, broadly defined consequential damages, and unrestricted punitive damages. That these are luxuries that Americans have acquired only recently, along with videocassette recorders and personal computers, is a matter of indifference.

Id. at col. 5.

Besharov \& Reuter further point out that holding American companies doing business abroad 
local consumers, a response that neutralizes the pohcy choices made in the alternative forum. ${ }^{185}$

Under this analysis, the Holmes court's overreaching to apply California law may have been altruistic and high-minded im design, but imperiahistic in result. A New York District Court imphed as much in its recent analysis of a similar paradox presented by the Bhopal disaster litigation. The court wrote:

It would be sadly paternalistic, if not misguided, of this Court to attempt to evaluate the regulations and standards imposed im a foreign country....

....

... [T]o retain the htigation in this forum, as plaintiffs request, would be yet another example of imperialism, another situation in which an estabhished sovereigu inflicted its rules, its standards and values on a developing nation. ${ }^{186}$

Charges of imperialism can run both ways, of course, which may be one reason to avoid thein altogether. Refusing to "inflict" our standards on a developing nation - by granting a forum non conveniens dismissalmay be more "sadly paternalistic." In imternational product hability cases like Holmes, for example, there is the sense that in the real world, rather than the legal world in which the inotion is heard, a real cause of

to U.S. standards of tort liability impedes their ability to compete in the local markets against local companies not exposed to similar risks. Id. at col. 4.

See also Note, supra note 154, at 223.

185. See Besharov \& Reuter, supra note 184.

Even if the U.S.'s trade competitors were willing to adopt the U.S.'s high level of liability, it is doubtful that Third World peoples would want to buy it, embedded in exports and investments. It is a fact they tolerate lower product and workplace safety than Americans do because they value economic development more highly than safety-just as the U.S. once did.

Id. at col. 5. Cf. Currie \& Schreter, supra note 175, at 1366-67 (unjustified impairment of other forum's interests for California to apply its law to workers' compensation claim of New York citizen hired in California to work in Alaska, where he was injured) ("In the pursuit of its altruistic interests, a state must stop short of treading upon the interests of otler states . . . It is one thing for a state to be generous to nonresidents at the expense of its own resideuts and enterprises; it is quite another to be generous to nonresidents at the expeuse of other nonresidents, or even of residents, or local enterprises, whose activities bring them witlin the protection of anotlier state's policy. .... At most, California can assert an altruistic interest in extending the benefits of its laws to nonresidents where the burden is borne by California enterprise; but that interest must yield when it conficts with a direct interest on the part of anotlier state.").

Moreover, American courts routinely recognize judgments issued by foreign courts against American citizens. See, eg., Hilton v. Guyot, 159 U.S. 113 (1895). This practice implicitly recognizes that many jurisdictions raise no serious questions of fairness or incompetence even though they may provide recoveries which are inadequate by American standards. Comment, supra note 10, at 387. See Note, supra note 154 , at 214 . It is inconsistent with this tradition of comity to routinely deny forum non conveniens motions whenever there might be an unfavorable change in law.

186. In $R e$ Union Carbide Corp. Gas Plant Disaster, 634 F. Supp. 842, 864, 867 (S.D.N.Y. 1986); see Harrison v. Wyetl Laboratories, 510 F. Supp. 1, 4 (E.D. Pa. 1980), aff'd mem, 676 F.2d 685 (3d Cir. 1982). 
injuries to innocent plaintiffs is American companies' use of underdeveloped nations as a safe harbor for mdustrial expansion. Thus framed, the issue becoines less whether we are subjectimg foreign countries to American standards of hability, and inore whether we are forcing innocent foreign citizens to share disproportionately in the risks of American business enterprises.

More to the point, recognizing the relevance of the state's substantive interest does not justify factoring the possibility of an unfavorable change of law into the forum non conveinens calculus. That possibility is an inadequate proxy for the intensity of a forum's interest, or even for the existence of an imterest. A foruin's interest in the application of its substantive pohicies depends on its connection to the case, not on the policy decisions of other forums. ${ }^{187}$ The question a court seeking to apply a substantively driven conception of forum non convemens would address is, "How substantial is this forum's connection to the case?" The possibility of an unfavorable change in law does not speak to that question. ${ }^{188}$

The Holmes court's approach compounded this problein by not only factoring in the possibility of an unfavorable change in law, but givmg it substantial, and perhaps conclusive, weight. Allowing the possibility of an unfavorable change $m$ law to weigh so heavily deprives foruin non convemiens of the equitable benefits it offers as a discretionary doctrine. Taking notice that a less favorable law will apply hardly requires an exercise of discretion, ${ }^{189}$ and the effect of incorporating it into a discretionary doctrine is to insulate froin direct scrutiny the kind of decision most appropriately reviewed de novo. ${ }^{190}$

Moreover, the substantial role the Holmes court assigned to the possibility of an unfavorable change im law deprives the foruin non convemiens doctrine of any independent vitality. In inost forum non convemens disputes, the law of the alternative foruin is likely to be less favorable to the plaintiff who is contesting the inotion. An unfavorable change in law will be the almost mevitable result of granting a forum non

187. It might be appropriate for a court to look to the law of the alternative forum to determine if it is identical to its own. Under a substantive model, this might weigh in favor of granting a formm non conveniens motion, since dismissal would not defeat the fornm's interest. Even in such a case, however, the alternative forum's law does not speak to the home forum's interest, but only to the absence of a confict in policies.

188. In fact, although few cases would present the question, a forum's interest could be equally disserved by a change of law favorable to the plaintiff. Under a substantive approach, the possibility of a favorable change in law would be no more or less signifieant than the possibility of an unfavorable change in law. This again is because the issue is the interest of the hoine fornm, which is completely independent of the policy of the alternative forum.

189. The same can be said of according substantial deference to the plaintiff's choice of forum, a further indication that that factor is meant to allocate the burden of proof in a fornm non conveniens inquiry, not to be part of the trial court's discretionary analysis. See supra text accompanying notes 102-17.

190. Cf. Stein, supra note 8 , at 840 . 
conveniens dismissal. The effect of the Holmes court's approach, therefore, is to merge forum non conveniens and choice of law into a single inquiry. Dismissal will likely be foreclosed where the forum has an interest sufficient to justify application of its own law. If forum non conveniens is to have a meaningful role, however, it must address questions other doctrines do not answer. Otherwise, it might just as well be abolished as a superfluous step whose purposes already are served by other litigation-allocation doctrines. ${ }^{191}$

\section{CONCLUSION}

The opinion of the court of appeal in Holmes misinterpreted precedent and served none of the policies that drive the forum non conveniens doctrine. The case nevertheless may be valuable in pointing the way towards a role for substantive concerns in the forum non conveniens inquiry. Decisions about what is convenient to the court inevitably contain judgments about the forum's connection to the litigation and necessarily implicate the state's interest in the application of its substantive policies. Although substantive concerns should not be conclusive, factoring them into the forum non conveniens calculus is consistent with the doctrine's role as an equitable, discretionary, and unique litigation-allocation device.

However, taking account of an unfavorable change in law is not justified even under a substantive model of forum non conveniens. An unfavorable change in law is a poor proxy for the home forum's interest in or connection to the litigation. Furthermore, giving substantial weight to the possibility of an unfavorable change in law conflicts with the discretionary nature of the doctrine, and, because forum non conveniens disputes so frequently are driven by a desire for the more favorable substantive law, it deprives the doctrine of any independent role.

Harry Litman*

191. See Stewart, Forum Non Conveniens: $A$ Doctrine in Search of $A$ Role, 74 CaL1F. L. REv. (forthcoming July 1986); see also Stein, supra note 8, at 784-85:

[C]ourts invoking the [forum non conveniens] doctrine have taken into consideration the very question purportedly addressed by jurisdiction, venue, and choice of law: which government has the appropriate relationship to the parties and the controversy to justify resolving the dispute in its courts or under its law. ... So used, the forum non conveniens doctrine has come to accommodate the collective shortcomings and excesses of modern rules governing jurisdiction, venue, and choice of law.

* B.A. 1981, Harvard University; third-year student, Boalt Hall School of Law, University of California, Berkeley. 
